\title{
"Nada de sexo sob o meu teto": sexualidade adolescente nos EUA e nos Países Baixos a partir dos anos 1880"1
}

\section{Cas Wouters}

Resumo: A tirada "nada de sexo sob o meu teto" é usada para reforçar a regra de abstinência sexual pré-matrimonial até os filhos adolescentes casarem ou saírem de casa. Nos EUA, a maioria dos pais ainda mantém-se ligada a essa norma, enquanto nos Países Baixos, desde o final da década de 1960, uma nova regra se desenvolveu, permitindo que os filhos adolescentes fizessem sexo desde que eles "sentissem algo forte um pelo outro" e se sentissem "prontos" para isso. Este artigo descreve e compara desenvolvimentos nos EUA e nos Países Baixos a partir de 1880, focando na regulação social da sexualidade adolescente e baseando-se principalmente em fontes como livros de etiqueta ${ }^{2}$ e estudos de sexologia. $\mathrm{O}$ artigo propõe uma explicação das duas trajetórias a partir de diferenças nacionais no funcionamento das boas sociedades, particularmente na regulação da competição social e da mobilidade social.

\footnotetext{
${ }^{1}$ Agradecemos a gentil autorização dada por Cas Wouters para a tradução e publicação do artigo "'No sex under my roof': Teenage sexuality in the USA and in the Netherlands since the 1880s". Politica y Sociedad, Vol.50 Núm 2: 421-452, 2013. Tradução: Jorge Henrique Silvestre Barbosa; revisão técnica: Fernando de Jesus Rodrigues.

${ }^{2}$ Reference books, no original (N. T.)
}

Latitude, Vol. 11, no 1, pp. 09-72, 2017

DOI: https://doi.org/10.28998/2179-5428.20170102B 


\section{"'Nada de sexo sob o meu teto': sexualidade adolescente nos EUA e nos Países Baixos a partir dos anos 1880"}

O surgimento, nos EUA, de um sistema de encontros (dating system) altamente competitivo e uma complicada moralidade sexual, indica um menor declínio da diferença de poder entre classes, gêneros e gerações, o que parcialmente explica a persistência da velha regra. Explicação adicional é encontrada no baixo nível de integração social da América e na competição mais aberta entre vários centros de poder e de boas sociedades. A preparação para a emergência de uma nova regra entre os pais holandeses foi uma informalização do "ficar noivos", a difusão do verkering (ficar estável $\left.{ }^{3}\right)^{4} \mathrm{e}$ das políticas parentais de

3 "Going steady", no original. (N. T.)

${ }^{4} \mathrm{O}$ desdobramento do "ficar estável" (going steady), como será mostrado ao longo do artigo, será o namoro, que servirá de opção quando em inglês, no original, a palavra "dating". A opção pela palavra "namoro" se baseia na busca por um termo português brasileiro que expressasse a flexibilização do noivado ou, nos termos de Wouters, sua informalização. É prudente chamar a atenção para as diferenças na condensação de experiências emocionais e normativas expressas em verkering e as encarnadas em "namoro", algo que inspira, a partir do artigo de Wouters, uma nota comparativa. O termo namoro é claramente o que expressa a maior afronta ao regime normativo do noivado das classes médias brasileiras entre os anos 60 e 70, a ponto de ele ter sofrido barreiras para ser utilizado publicamente como o reconhecimento de uma nova experiência amorosa-sexual, como podemos depreender de Thales de Azevedo: "o namoro conduz e obriga ao noivado e ao casamento. Por isto, em certas regiões do país, a palavra namorado é tabu. A moça não fala abertamente em "meu namorado" mas "nesse rapaz que eu gosto", ou usa outros eufemismos. Também por isso as moças muito "oferecidas" ou que facilmente aceitam um namoro perdem prestígio e renome. Um namoro "muito falado" é, por sua vez, aquele que se desenrola sem obediência às mencionadas regras do recato. (Azevedo, Thales de. "Fazer a corte no Brasil: o namoro e a paquera" In: Cahiers 
ficar "na cena", indicando níveis mais altos de integração social e maiores declínios das diferenças de poder entre classes, gêneros e gerações. No entanto, a longa preservação de uma boa sociedade homogênea, criou um disparidade crescente entre a fachada de decência e as realidades dos bastidores. Quando essa disparidade foi varrida nas Revoluções Expressiva e Sexual dos anos 1960, ela também levou consigo a velha regra, e crescentes números de pais permitiram abertamente que seus filhos fizessem sexo, mesmo em casa.

Palavras-chave: sexualidade adolescente, competição por status, EUA, Países Baixos, informalização

Sumário: Introdução: O caminho para tocar e abraçar e beijar. 1 . Pontos de partida teóricos: Balanças. 2. Cortejando nos EUA. 3. $\mathrm{O}$ dating americano. 4. O legado social do dating: o início da perda da liderança. 5. Enquanto isso, na Europa... 6. Os Países Baixos da Europa. 7. Uma visão teórica sobre livros de boas maneiras e as funções da "boa sociedade". 8. Explicando diferentes trajetórias nacionais de regulação da sexualidade adolescente. 9. Notas de conclusão.

\section{Introdução: o caminho para tocar, abraçar e beijar}

Nas boas sociedades da Europa e dos EUA do século XIX, o código dominante que regulava o acesso ao caminho para tocar, abraçar e beijar era muito similar. Exigia que os jovens primeiramente se comprometessem a noivar, um compromisso público cerimonial para casar. Apenas o

du monde hispaine et luso-brésilien, no ${ }^{\circ}$ 30, 1978, Numéro consacré au Brésil, pp. 117-126.) 


\section{"'Nada de sexo sob o meu teto': sexualidade adolescente nos EUA e nos Países Baixos a partir dos anos 1880"}

casamento abria a porta para intimidades físicas outras. Os acompanhantes funcionavam como bloqueadores da corporalidade precoce. Os jovens poderiam ir acompanhados a eventos sociais específicos, tais como jantares, festas e bailes, a maioria deles oferecidos em salas de estar de seus pais ou de outros adultos também inseridos nas redes de relacionamento da boa sociedade. $\mathrm{O}$ garoto era aconselhado a não dançar mais do que duas vezes com a mesma garota, se o fizesse, alguém poderia supor que ele tinha "olhos para ela", despertando, desta forma, expectativas e, portanto, obrigações. Se um jovem rapaz quisesse conhecê-la mais do que era possível no salão de festa, ele deveria:

ir aos pais da garota e pedir a eles, pessoalmente, permissão para fazer-lhes uma visita. Se os pais não estiverem presentes no baile, você pergunta à garota e a indaga sobre o "dia de visitas" da mãe dela. Entretanto, você ainda deve perguntar aos pais se eles podem recebê-lo, e fazer a visita dentro de duas semanas depois do baile. Se sua pessoa for apreciada, eles pedirão que você volte outra vez e não esperarão muito antes de convidá-lo. (ECvdM, 1911, p. 106-7)

Quando ele solicitava, era recebido na sala de estar, antessala ou, nos EUA, na sacada. Em cada caso, alguém estaria presente ao encontro ou a uma distância de se ouvir a conversa. O rapaz poderia ser convidado a fazer uma nova visita, ou não, e ele poderia, é claro, declinar do convite. Mas, caso seus pedidos fossem contínuos, era esperado que essas visitas 
culminassem em sua proposta de casamento: "se depois de um tempo razoável nenhuma proposta de casamento é feita, seria bom deixar a amizade passar com o derretimento da neve do inverno ou com a queda das folhas de outono, a depender da estação do ano" (WADE, 1924, p. 116). Estas descrições trazem claramente à tona a grande distância que era esperada que os sexos mantivessem entre si, e também, como cada passo estava, em direção à atenuação dessa distância, no centro do olhar público e bem vigiado dos pais e da família da garota.

Se uma proposta se seguiu e ela e seus pais a aceitaram, primeiro o casal se torna "comprometido" a casar. Um "noivado" também servia para o casal se conhecer um ao outro melhor. Embora a experimentação sexual estivesse explicitamente excluída, era mais ou menos esperado e aceito que ao menos algumas intimidades sexuais ocorreriam. Por isso, as boas maneiras $e^{5}$ sua reputação requeriam que fosse a jovem a terminar o noivado. Um homem que o fizesse era descrito como um cafajeste, então "a única coisa que ele poderia fazer era provocá-la para que pusesse fim ao compromisso" (ECvdM, 1911: 114). Já que era geralmente esperado que muitos casais "cairiam" e cederiam à tentação se a oportunidade fosse dada, o casal respeitável, mesmo quando noivo, não seria deixado muito sozinho; isso prejudicaria suas reputações. Este era o regime de cortejo prevalecente. Sua localização principal era a sala de estar.

Então, a partir do final do século XIX em diante:

${ }^{5}$ Grifo do autor. (Todas as palavras ou letras destacadas em itálico serão correspondentes a grifos feitos pelo autor no original, exceto no caso de palavras estrangeiras, onde a regra nos obriga a também destacá-las em itálico). (Nota do tradutor) 


\title{
“'Nada de sexo sob o meu teto': sexualidade adolescente nos EUA e nos Países Baixos a partir dos anos 1880"
}

\begin{abstract}
Em toda a vida social houve, verdadeiramente, o início de uma preparação para que mulheres respeitáveis se encontrassem em lugares públicos fora de suas próprias casas. Cafés, o crescimento das salas de chá, o uso de ônibus, até mesmo a preparação de banheiros públicos para mulheres, foram tão importantes para a libertação das mulheres de classe média do rigoroso rito social, quanto a lenta erosão das acompanhantes. Contato por telefone e a posterior mobilidade que veio com os carros, começaram a minar a maioria dos elementos formais da etiqueta. (DAVIDOFF, 1973, p. 67)
\end{abstract}

O historiador Porter adiciona a importância da "chegada da bicicleta e a prática de mais esportes pelas mulheres" (1972, p. 81). A coeducação também desempenhou seu papel. Em geral, "modelos alternativos de feminilidade - a mulher universitária ou até mesmo a sufragista - ofereceram 'carreiras' que competiam, com algum sucesso, contra a Sociedade do bom gosto" (CURTIN, 1987, p. 243-4).

Até a Segunda Guerra Mundial, na Europa e nos EUA, as tendências foram na mesma direção da emancipação das gerações mais jovens e de suas sexualidades, bem como da emancipação das mulheres e de suas sexualidades. Tanto as relações de cortejo quanto os noivados começaram a ficar cada vez mais carregados de sexualidade. Mais especificamente, o processo foi em direção a uma maior liberdade para controlar a dinâmica dos próprios relacionamentos, fossem eles românticos ou não, e para decidir sobre a respeitabilidade das condições e dos lugares de encontro. Nos EUA, essa emancipação se 


\section{Cas Wouters}

desenvolveu através do sistema de encontros ${ }^{6}$ estabelecido nos anos 1920, na Europa via uma informalização dos noivados (formais) e um crescimento do verkering ou "namoro". Depois da Segunda Guerra Mundial, as diferenças nacionais diminuíram, apesar de os legados sociais dessas duas diferentes trajetórias ainda serem bastante perceptíveis. Nesse contexto, esse artigo lança a questão das diferenças na regulação nacional da sexualidade dos adolescentes: por que a regra de que os pais americanos devem exigir abstinência completa da sexualidade de seus filhos adolescentes até eles saírem de casa ainda é dominante nos EUA, e por que os holandeses têm aberto mão dessa regra, particularmente desde o final dos anos 1960, através da permissão da sexualidade pré-marital?

A socióloga americana Amy Schalet iniciou a comparação das diferenças na regulação da sexualidade adolescente entre os EUA e os Países Baixos lançando a questão de por que a maioria dos pais holandeses permitiria condicionalmente que seus adolescentes fizessem sexo "sob seus tetos", enquanto a maioria dos pais americanos jamais autorizaria isso (1994; 2011). Até o início dos anos 1970, entretanto, muitos pais holandeses também proibiriam e até usariam a mesma expressão "não sob o meu teto". Desta forma, este artigo desenvolve uma explicação histórica mais abrangente dessas diferenças nacionais. Ele é construído a partir dos meus estudos "Sex and Manners" (2004) e "Informalization" (2007), integrando novo material à história social do noivar e à longa preservação de um establishment homogêneo nos Países Baixos. Esse material me fez enfatizar o significado da perda das classes altas americanas de uma batalha cultural para as classes médias e para grupos de iguais.

${ }^{6}$ Dating system, no original. 


\section{"'Nada de sexo sob o meu teto': sexualidade adolescente nos EUA e nos Países Baixos a partir dos anos 1880"}

A confrontação direta e a comparação dos dois países destaca, assim, a maneira como diferenças na regulação social da sexualidade adolescente estão conectadas à regulação da competição e mobilidade sociais.

Após apresentar alguns pontos de partida teóricos na próxima seção, eu descreverei e compararei as duas trajetórias nacionais e seus legados sociais atuais. As seções finais objetivam uma interpretação dos dois desenvolvimentos.

\section{Pontos de partida teóricos: balanças}

Minha caixa de ferramentas para comparações internacionais e históricas contém um número de padrões, conceituados como balanças que são universais no sentido de que eles podem ser frutiferamente aplicados a vários países e a diferentes períodos. Juntos, eles abrem uma janela para os níveis de diferenciação e integração de uma sociedade, bem como para a extensão e a densidade de suas redes de interdependência. Aqui, eu me restringi a mencionar as mais relevantes para este artigo ${ }^{7}$.

A primeira balança é a balança de poder. Na medida em que os indivíduos crescem, eles se tornam menos dependentes de seus pais, e é um fato geralmente aceito que esta mudança

7 Outras balanças são as do envolvimento e alienação, a balança NósEu, e a balança da competição e cooperação, que marca até onde há competição na cooperação e cooperação na competição. Em regra, esta balança está estreitamente relacionada à balança trabalho e diversão, que observa o quanto de trabalho está inserido na diversão e o quanto de diversão está inserido no trabalho. Ambas abrem uma janela sobre o nível de diferenciação e integração dentro das redes de interdependência. (Nota do Autor, doravante N.A.) 
também tem ocorrido através de gerações: ao longo do século $\mathrm{XX}$, os pais cada vez mais levaram em conta as necessidades e desejos de seus filhos e filhas. Assim, as mudanças do século XX nos códigos dominantes de cortejo e sexualidade, refletem transformações nas balanças de poder entre as gerações e os sexos.

Uma segunda balança é a balança dos controles: entre controles sociais externos e aqueles internos, ou autocontroles. Ao longo do século $X X$, esta balança continuou mudando de uma ênfase nos controles externos para uma ênfase nos autocontroles. Ao se livrarem das acompanhantes, por exemplo, as mulheres tiveram de se tornar suas próprias acompanhantes e fazerem elas mesmas o cortejo. Elas passaram a ser donas dos seus narizes, e como elas vieram a ser cobradas e esperadas a agir assim, os controles sociais começaram, gradualmente, a estar focados nos autocontroles. Esta tendência foi reforçada de muitas formas, por exemplo, pelo crescimento da afluência e sua expansão via programas do Estado de bemestar social. Isso desencadeou um declínio no nível social de suspeita e medo mútuos, e um crescimento no nível de confiança mútua, ou, formulado em termos da balança de controles, um crescimento do nível de autocontroles mutuamente esperados. "Indivíduos são compelidos a regular suas condutas em um modo crescentemente diferenciado, mais equilibrado e mais estável" (ELIAS, 2012, p. 406).

Uma terceira balança é aquela da formalização e informalização. Historicamente, o processo de longa duração da formalização das maneiras (e disciplinamento das pessoas) no "Ocidente", se refere à sujeição de cada vez mais aspectos do comportamento a regulações cada vez mais estritas e detalhadas, parcialmente formalizadas como leis, parcialmente 


\section{"'Nada de sexo sob o meu teto': sexualidade adolescente nos EUA e nos Países Baixos a partir dos anos 1880"}

formalizadas como maneiras. Informalização se refere a uma tendência que se tornou dominante a partir do final do século XIX em diante, uma tendência em direção a uma extensão mais abrangente de alternativas comportamentais e emocionais socialmente aceitas, uma transformação de regras fixas para diretrizes flexíveis, a depender dos vários tipos de situações e relações. Esta extensão mais abrangente de opções caminhou de mãos dadas com o cada vez mais atento escrutínio das escolhas feitas, desencadeando não apenas uma maior flexibilidade e reflexividade mas também uma "emancipação das emoções" a qual incluiu uma emancipação da sexualidade, um processo de sexualização.

A última balança a ser mencionada é a balança do desejo: entre o anseio por gratificação sexual e o anseio por uma intimidade duradoura, entre sexo e amor. Nas boas sociedades da Europa e dos EUA, das últimas décadas do século XIX em diante, a tradicional balança do desejo de uma sexualidade dominada pelo desejo para os homens e uma sexualidade complementar (romântica) dominada pelo amor ou relacionamento para as mulheres, tem sido modificada em direção a uma "sexualização do amor" e uma "erotização do sexo", provocando novas e mais variadas respostas à seguinte pergunta ligada à balança do desejo: quando ou dentro de qual(is) tipo(s) de relacionamento(s) são permitidos ou desejados (quais tipos de) erotismo e sexualidade?

\section{Cortejando nos EUA}

Dos anos 1880 até os anos 1920, as maneiras de cortejar geralmente mostraram o mesmo desenvolvimento global: pessoas jovens começavam a se encontrar, isto é, sair juntos, 


\section{Cas Wouters}

ambos com ou sem um(a) acompanhante. A completa vigilância por via de acompanhantes foi erodindo assim como o sistema de "convite", ele visitando-a na casa dos pais dela. Por volta da metade dos anos 1920, conselhos sobre encontrar, agarrar ${ }^{8} \mathrm{e}$ acariciar, a "cantada", a parede de solteiros, chegar junto e ficar travado, tinham aparecido na maioria dos livros de boas maneiras americanos, e somente nos americanos, assinalando o estabelecimento do "sistema de encontros" (dating system) americano. Ele apoiava-se sobre um código dos jovens que abertamente se contrapunha ao velho código adulto formal do "convite", no qual encontros acompanhados preparavam para um noivado e, então, um casamento.

As classes altas americanas, assim como suas homólogas europeias, eram mais fortemente motivadas a salvaguardar suas filhas de encontros com "candidatos inadequados" do que as classes médias, o que explica porque o velho código mais formal dos adultos se manteve mais tempo preservado nestes círculos. Dentro do espectro dos livros de boas maneiras, autoras como Emily Post e Amy Vanderbilt representaram este código formal (adulto) da classe alta. $\mathrm{O}$ americano Edmund Wilson diferenciou Lilian Eichler, autora de um livro de boas maneiras bem sucedido nos anos 1920, da senhora Post. Eichler, ele escreveu, "faz a vida social soar fácil e alegre", mas a senhora Post parece "acreditar na existência de um Olimpo social" e "sempre supõe que o leitor quer pertencer à Sociedade" (WILSON, 1962, p. 382). Esta orientação tradicional da classe alta demonstra porque Emily Post ignorava a existência das "carícias" em suas primeiras edições dos anos 1920, e por que, na sua edição de 1931, ela declarou o tópico

${ }^{8}$ Em linguagem popular brasileira: cafungar. (Nota do revisor técnico, doravante N. R. T.) 


\section{"'Nada de sexo sob o meu teto': sexualidade adolescente nos EUA e nos Países Baixos a partir dos anos 1880"}

como "bastante fora do assunto etiqueta - tão fora que ele não tem mais lugar dentro da sociedade distinta do que quaisquer outras ações que sejam baratas, promíscuas, ou vulgares" (POST, 1931, p. 297). Em resumo, a senhora Post ignorou o surgimento e o estabelecimento do sistema de encontros (dating system).

A senhora Post também permaneceu ambivalentemente conservadora sobre o declínio do(a)s acompanhantes. $\mathrm{Na}$ edição de 1937 de seu livro, um lado de sua ambivalência é representado ao escrever: "de um ponto de vista ético, a única acompanhante digna de se ter nos dias atuais é a eficiência da própria jovem em acompanhar a si própria". O outro lado de sua ambivalência negligencia esta mudança da proteção pelo acompanhamento para a autoproteção pelo treinamento. Sob esse ângulo, ela se apega à necessidade das acompanhantes porque "ainda há as aparências a serem levadas em conta" (POST, 1937, p. 353-4). No mesmo fôlego, ela questiona a capacidade de qualquer jovem garota conseguir se proteger:

E ainda - qualquer tentativa de aplicar as regras de propriedade às idas desacompanhadas de uma jovem garota ao apartamento de um homem, seria o mesmo que tentar dar direção a chamas aplicadas sobre explosivo altamente inflamável... isto é, permitir um certo elemento de atração entre a mulher e o homem. (POST, 1937, p. 358)

Em suma, a senhora Post pensou que o(a) acompanhante tinha que permanecer em funcionamento por duas razões: primeiro para acomodar a senhora Grundy - sua 


\section{Cas Wouters}

personificação da fofoca depreciativa e de outras formas de controle social externo - e segundo, pela falta de confiança na força do autocontrole. Sua ambivalência sobre a acompanhante durou até os anos 1940.

A edição de 1960 do livro de boas maneiras de Post não continha mais a seção que lançava dúvidas sobre a capacidade das jovens de proteger e reprimir a si mesmas quando sozinhas com um homem. Nas edições de 1952 e 1963 do famoso livro de etiqueta de Amy Vanderbilt, no entanto, essa forte convicção foi expressa para os casais de noivos:

Se os jovens não quiseram fazer amor na maior parte do tempo durante seu período de noivado, isso não pareceria normal. ... Para noivos de todas as idades, a sociedade espera um acompanhamento de algum tipo. Eles podem, é claro, ficar longos dias e noites juntos sozinhos, mas eles não devem sair por um fim de semana inteiro ou por um pernoite, a menos que adequadamente acompanhados. (VANDERBILT, 1952, p. $126 ; 1963$, p. 13)

Estas referências a "noivos de todas as idades" foram as últimas exceções à gradual regra estabelecida de que as palavras acompanhante e acompanhamento se referiam apenas às crianças, agora não mais demarcando a transição da adolescência para a idade adulta, mas da infância para a adolescência.

Considerando que Post e Vanderbilt representavam o código (adulto) formal, muitos outros autores representavam o código da juventude mais de classe média e mais informal pela 


\section{“'Nada de sexo sob o meu teto': sexualidade adolescente nos EUA e nos Países Baixos a partir dos anos 1880"}

discussão do sistema de encontros (dating system) e suas carícias inerentes. Um autor contradisse enfaticamente a senhora Post em um livro dirigindo-se às garotas, que são, como calouras do campus universitário, "ainda uma aventura para os homens":

Então, claro, você quer aproveitar ao máximo sua novidade. Com habilidade, você pode construir uma popularidade duradoura para você no resto dos seus quatro anos de faculdade no campus. Se você tem encontros frequentes, terá muitas oportunidades de "agarrar-se", a despeito da afirmação de Emily Post de que as carícias não têm lugar na sociedade polida. (Garotos universitários, aparentemente, nunca leram o livro dela.) ... Todos eles estão francamente curiosos para descobrir se você é uma "descolada" ou uma "sem graça". Isto, você deve determinar por você mesma... (ELDRIDGE, 1936, p. 176)

Aqui, Post é ridicularizada por sua elitista falta de qualquer senso das ruas (os grupos de iguais da classe média). Isso expressa o sentimento de estar liberto da rigidez da classe alta. A experiência de vencer uma luta de classe e de status pelo estabelecimento do sistema de encontros (dating system), ajuda a explicar por que este sistema se tornou um orgulhoso símbolo nacional de liberdade.

\section{O sistema de encontros (dating system) americano}

Em seu estudo sobre este sistema, Beth Bailey leva em conta um período de transição, no qual um garoto pode ter 
recebido um "convite", esperando ser recebido na sala de estar de sua família, enquanto ela "coloca o chapéu", esperando um "date", isto é, ser "retirada" para algum lugar e entretida em algum local público ou de divertimento comercial. Nos EUA, junto com a palavra "date", toda uma família de palavras e práticas entraram na cultura jovem e foi desenvolvida mais tarde. Os códigos dos encontros tornaram-se elaborados o suficiente para se falar em um sistema de encontros. Por volta da metade dos anos 1920, o encontro (dating) já tinham substituído quase que completamente o velho sistema do convite (calling system).

$\mathrm{O}$ aparecimento do sistema de encontros significa o escape dos jovens de debaixo das asas dos pais e a formação, por suas contas próprias, de um regime de cortejo relativamente autônomo. Este regime foi uma novidade na história da relação entre os sexos, e conduziu à vanguarda da emancipação da sexualidade e à primeira cultura jovem restrita aos EUA em contraste com a cultura jovem dos anos 1960, algo de um Ocidente internacional. A sociogênese do sistema de encontros pode ser esboçada com as seguintes seis características singulares americanas.

1) Cultura jovem e encontros (dating) desenvolveram-se nas faculdades e campi mistos: estas cidadelas de jovens singularmente americanas permitiram uma emancipação dos grupos jovens de debaixo das asas de seus pais. Nos anos 1920, quando dois terços de todos os estudantes estavam em residências mistas de faculdades, elas foram capazes de fazer seu próprio código de comportamento de cortejo via solidariedade geracional contra a geração mais velha. Em seu estudo destes desenvolvimentos, Paula Fass mostra como "os jovens foram mais e mais orientando seus comportamentos 


\section{"'Nada de sexo sob o meu teto': sexualidade adolescente nos EUA e nos Países Baixos a partir dos anos 1880"}

para instituições não tradicionais - pares aos invés de pais, cinemas ao invés da comunidade local" (1977, p. 290).

Negociações entre as gerações ainda produziram novas aparências a serem mantidas: "todas as faculdades de boa reputação agora insistem em uma lista de benfeitoras que disponibilizariam suas presenças, assim como seus nomes aos bailes das fraternidades, como uma garantia de que estes divertimentos seriam conduzidos com o decoro inerente aos bailes privados" (WADE, 1924, p. 272). E "faculdades não permitirão uma festa em casa que seja insuficientemente supervisionada, e sem dúvida muitas mulheres de escol na comunidade agirão como responsáveis" (PIERCE, 1937, p. 18). Os jovens, no entanto, desenvolveram muitas formas de escaparem de suas supervisões: "acompanhantes eram convidadas, mas convenientemente postas na sala de estar, superficialmente envolvidas em conversas (com frequência, a tarefa do calouro), e mantidas longe de verem e ouvirem o que de fato acontecia ${ }^{9}$ nos salões de dança, áreas de entretenimento e espaços não iluminados na parte de fora" (FASS, 1977, p. 196). Portanto, escapar da supervisão poderia se tornar um ingrediente erótico e sexual do cortejo.

2) Sexo rapidamente se tornou a questão chave na luta pela emancipação dos jovens. Por volta dos anos 1920, a questão de "o quão longe ir" além de beijar foi abertamente debatida e os debates logo se centraram nas práticas de agarrar ${ }^{10}$ e acariciar. $\mathrm{O}$ compromisso era com um código jovem

9 "Real activity", no original. (N. R. T.)

${ }^{10}$ Evitamos o uso de palavras mais novas do vocabulário eróticosexual brasileiro como "ficar", "pegar" ou "pegação", por expressarem novos equilíbrios entre níveis de intimidade e tipos de flexibilidade do relacionamento erótico-sexual em comparação com os 
que permitia alguma atividade sexual, mas explicitamente não se podia "ir até o fim do caminho". Neste sentido, o namoro ${ }^{11}$

associados a termos como "agarro" ou mesmo "flerte" que, como destaca Azevedo (1978, p. 120), a partir de textos de João do Rio, também poderia significar pegar e tocar em contextos de trocas amorosas-sexuais desde o início do século XX.

${ }^{11}$ Notar que, em inglês, "to date" ou "date" têm o sentido mais forte de "encontrar", expressando a dinâmica de experimentos de companhia anterior a um compromisso o qual, no Brasil, é estritamente compreendido como namoro, mesmo que também abarque o sentido de namorar brasileiro, significando encontrarem-se de forma comprometida publicamente, de modo frequente e duradouro, para ter prazeres com uma companhia, ambos abertos a alguma intimidade erótico-sexual. "Dating", por sua vez, é palavra mais associada às formas substantivas "namoro" ou "namorar", já como decorrência de um comprometimento mais firme posterior a encontros de experimentação de afinidades. No entanto, para indicar o sistema social que leva ao comprometimento amoro-sexual traduziremos system of dating por sistema de encontros, enquanto que namoro ficará reservado para traduzir dating quando indicar simplesmente o relacionamento que envolve intimidades amorosassexuais sem o compromisso de casar ou noivar. Esse nome expressa a legitimidade da experiência de se ter a companhia erótico-sexual de alguém, sem compromissos com um noivado ou casamento. No Brasil, não temos uma palavra específica que designe um período de experimentação pública anterior ao namoro, cujo reconhecimento público ainda estava, nos anos 60 e 70, muito associado a um compromisso de noivado. Geralmente, tal período foi tratado como um evento não divulgável, não público, levantando-se fortes barreiras para que ganhasse um termo específico, talvez, entretanto, o nome "namorico". O que havia de mais legítimo era a "paquera", palavra associada a dinâmicas de aproximação mais distanciadas, como olhares, cartas e o intercâmbio ambivalente das alcoviteiras. Os 


\section{"'Nada de sexo sob o meu teto': sexualidade adolescente nos EUA e nos Países Baixos a partir dos anos 1880"}

(dating) estava orientado para o sexo $e$ o casamento. Se a juventude universitária aderisse ao código adulto, poupando-se de "ir até o fim do caminho" até o casamento, seus anos de vivência sob o código da juventude permaneceriam sem riscos significantes no longo prazo, porque a comunidade do campus era temporária e afastada - uma condição que favorecia a pressão dos grupos de pares. Sob esta pressão, carícias logo tornaram-se uma necessária demonstração de conformidade. "Exploração erótica experimental era, com frequência, um fenômeno de grupo", escreve Paula Fass. "A festa dos agarros", ela conclui, "tanto forçou a exploração erótica, quanto controlou a finalidade do erotismo" (FASS, 1977, p. 266).

3) Conhecer diversos parceiros era defendido como uma boa preparação para a seleção do parceiro de casamento mais tarde. Um encontro (date) se desenvolvia em uma espécie de namorico que durava o mesmo tempo do encontro (date) e não tinha compromisso posterior. Consequentemente, a relação de casal de um encontro não era exclusiva: a medida em que o sistema de encontros (dating system) se desenvolvia, "encontrarse com uma dúzia" - ter inúmeros parceiros - foi encorajado, enquanto "ficar estável" (going steady) foi desencorajado e rejeitado como uma prática de covardes sem colhões para experimentar e decidir. Encontrar-se com uma dúzia deu início a uma instituição chamada de "cantada" ${ }^{12}$, um bem ensaiado e

encontros anteriores ao compromisso de namoro eram furtivos. "De repente", sabia-se que um casal estava "namorando". (N. R. T.)

${ }^{12} \mathrm{O}$ sentido de "line" está muito próximo das "coplas", falas teatrais e do teatro de revista, mas, historicamente, os brasileiros não fizeram esse vínculo na língua portuguesa. $\mathrm{O}$ diálogo entre falas estereotipadas e estratégias de aproximação e conquista amorosa- 


\section{Cas Wouters}

frequentemente repetido conjunto de frases usadas em contatos iniciais entre os sexos para lisonjear e cativar: "em vez de um mero 'você está bonita essa noite', você pode dizer em um barítono profundamente agitado, 'que o tom de azul destaca seus olhos'" (JONATHAN, 1938, p. 98-99). De fato, "um certo número de exageros é costumeiro entre garotos e garotas" (MCGINNIS 1968, p. 100). Nos encontros, assim como em todos os tipos de negociação, a ferocidade americana da competição relativamente aberta, desencadeou e permitiu exageros, vanglória e o uso de superlativos.

Depois da segunda guerra mundial, quando o "ficar estável" (going steady), ainda assim, tornou-se popular entre os adolescentes americanos, esta popularidade não afetou muito o sistema de encontros (dating system). Até então, o sistema havia se tornado uma instituição social tão firmemente enraizada, que "ficar estável" (going steady) era visto como passageiro: os jovens estavam "entrando e saindo de encontros" (dating). Desta forma, "ficar estável" (going steady) foi integrado ao sistema de encontros (dating system).

4) Nos encontros, enquanto garotos esperariam alguns agarros e carícias, as garotas tinham que aprender a "como conhecer a 'idade do jazz'13 pela metade, sem destruir nenhum dos velhos padrões da família" (SCHLESINGER, 1946, p. 54). Esse era o meio termo da menina boa-má, aquela que fez

sexual se desdobrou, no Brasil, a partir da música, a "cantada". (N. R. T.)

13 "Jazz age", no original. Metáfora que se vale do significado cultural e literal do termo, a saber: “o período dos anos 1920, nos Estados Unidos, caracterizado como um período de hedonismo, liberdade e exuberância." (Concise Oxford English Dictionary, 2006). (N.T.) 


\section{"'Nada de sexo sob o meu teto': sexualidade adolescente nos EUA e nos Países Baixos a partir dos anos 1880"}

Margaret Mead lembrar de uma copla ${ }^{14}$ do início do século XX: "- alguém não poderia me dar algum bom conselho sobre como ser malcriada e ainda assim ser boazinha?" Mead mostrou convincentemente, que durante o período do encontro, "há o imperativo de que alguém deve ser capaz de jogar com sexo o tempo todo, e ganhar. Quanto mais jovem for o garoto e a garota quando eles aprenderem a jogar este jogo parcialmente incompleto, de indulgência altamente controlada do impulso, mais perfeitamente eles podem aprendê-lo" (1950, p. 290-291). Este imperativo estimulou crescente sutileza na arte de se guiar "entre as rochas do pudor e da faceirice15" (HEMPHILL 1999, p. 110), pois, a fim de "permanecer a vencedora, ela deve fazer as melhores distinções entre complacência e rigidez" (GORER, 1948, p. 116).

5) $\mathrm{O}$ surgimento do sistema de encontros implica em que a autoridade dos pais sobre o cortejo de suas filhas fosse colocada nas mãos dos jovens rapazes. A medida que o controle sobre a juventude pela geração mais velha declinou, jovens rapazes dominaram o processo constitutivo dos códigos dos encontros. Com o dinheiro que eles gastavam em um encontro, os garotos compravam obrigação, o dinheiro deles comprava desigualdade, comprava controle: "quanto mais dinheiro o homem gasta, mais carícias a mulher deve a ele", e "boas garotas' custam bastante" (BAILEY 1988, pp. 23; 81). O trato holandês (pague suas próprias coisas) foi vigorosamente rejeitado. Se garotos vinham a ser anfitriões das garotas, garotos pagavam; eles tomavam a iniciativa e assumiam o controle que vinha com essa postura.

\footnotetext{
${ }^{14}$ Nome para falas teatrais que, no Brasil, ficou mais associado ao teatro de revista. (N.R.T.)

15 "Prudery and coquetry", no original. (N.T.)
} 


\section{Cas Wouters}

Era esperado dos garotos fazer investidas sexuais e suas atitudes são capturadas em uma frase de uma fraternidade dos anos 1920: "se uma garota não acaricia, um homem pode imaginar que ele não a impeliu do jeito certo" (STEARNS and KNAPP, 1992, p. 786). A responsabilidade pelo refreamento sexual foi colocada nas mãos das mulheres: garotos poderiam culpar a garota por todos os atos sexuais, até os não autorizados ou indesejados: ou ela não tinha colocado limites (a tempo), ou ela não era verdadeiramente virtuosa. Assim, aquela velha ideia aceita de que "garotos serão garotos", de que eles "naturalmente" desejariam alguma atividade sexual, e iriam "em frente", foi aceita e reforçada. Esta atitude instrumental em relação às mulheres foi formalizada no sistema de encontros (dating system). O comportamento universitário dos anos vinte desceu para o ensino médio nos anos 1930, e "ao menos a partir do início dos anos 1940, garotos de classe média conversavam em termos de forçar as carícias até onde suas namoradas permitissem, se não mais longe, descrevendo toda a experiência como 'divertir-se' ou 'levá-las para um passeio'" (STEARNS and KNAPP, 1992, p. 786).

6) Cada encontro e cada pessoa com quem se encontrava contava e era pontuada em uma disputa por popularidade. Como uma disputa social por popularidade, os encontros produziram uma mistura peculiar de aquiescência competitiva. Nos anos 1930, encontrar-se tornou-se uma busca competitiva por excitação e crescentemente mais sexualizada, e agarrar e acariciar tornando-se rituais controlados de exploração sexual contida. Práticas de cortejo tinham estimulado um "comportamento de busca por excitações" que transformou o cortejo em "um divertimento e em uma liberação de tensões orgânicas", e beijar em uma atividade que "pode implicar em 


\section{"'Nada de sexo sob o meu teto': sexualidade adolescente nos EUA e nos Países Baixos a partir dos anos 1880"}

um não comprometimento total da personalidade, seja ele qual for" (WALLER, 1937, p. 728). Entre seus pares, uma jovem mulher era "avaliada pelo nível de consumo que ela seria capaz de demandar (quanto ela "valeria"?), e o homem pelo nível de consumo que ele poderia prover" (BAILEY, 1988, p. 58). Encontrar-se tornou-se uma "atividade competitiva dominada pelo dinheiro e pelo consumidor presunçoso" (CALDWELL, 1999, p. 229), materializado, ainda, nos populares taxi-dance halls ${ }^{16}$, onde todo tipo de homem (com exceção dos "negros americanos") poderia ter acesso a jovens mulheres e garotas por "dez centavos a dança" (CRESSEY, 1932, p. 3)17. A pressão dos pares para se adequar à competição por popularidade significava que você tinha que pontuar para se encontrar e se encontrar para pontuar. Esta competição transformou os encontros em "um jogo de gato e rato emocionalmente constrangedor de seduções ensaiadas e "marcação de pontos'" (FASS, 1977, p. 271), uma competição por pagar e acariciar que empurrou todos os participantes em direção à maior exploração do caminho do desejo. A atitude competitiva, instrumental e comercial que foi institucionalizada no regime de encontros, foi estendida ao "pontue e tenha um encontro" (WALLER, 1937), tanto quanto foi estendida ao "pague e acaricie", e desde os anos 1960, a um expansivo consumo massivo de sexo comprado em um mercado. Outro legado social do "pague e acaricie" é identificado como "cultura vulgar", exibindo grandes números de "mulheres porcas chauvinistas" (Levy 2005). Comprar sexo e explorar sexo em relações preferencialmente mais voláteis,

16 "Taxi-dance halls", no original. (N.T.)

${ }_{17}$ Nesta introdução ao "The taxi-dance hall", Cressey escreveu que entre 1925 e 1932 este se tornou "o tipo dominante de salão de dança nos centros de negócios das nossas maiores cidades". (Nota do autor) 
comerciais e instrumentais pode ser interpretado como continuações de formas de comportamentos que eram altamente valorizados no sistema de encontros. Eles sugerem a continuação de uma balança do desejo enfatizando o anseio mais forte por gratificação sexual do que o anseio por intimidade duradoura.

\section{O legado social do sistema de encontros: o início da perda da liderança}

Para entender esta comercialização do sexo, isto é, porque as mulheres americanas permitiram que pagar e acariciar se tornassem conectados, parece importante comparar o surgimento do sistema de encontros como uma "cultura jovem" americana com a segunda cultura jovem internacional dos anos 1960. Esta última foi logo seguida por uma onda de emancipação das mulheres do controle dos homens: no final dos anos 1970, o movimento das mulheres em todos os países ocidentais se voltaram contra a violência sexual, isto é, contra a dominação masculina. Nos EUA dos anos 1920, entretanto, a libertação do regime das gerações mais velhas e de seu tabu do absolutamente-nada-de-sexo, não foi seguido pela libertação da dominação e opressão sexual masculinas. O sistema de encontros dos Estados Unidos, os códigos relativos ao pague e acaricie, em particular, podem ser interpretados como uma consequência e como prova desta ausência.

A gradual aceitação social do amasso, nos anos 1920, porém sem "ir até o fim" explicitamente (e camisinhas eram ilegais e difíceis de conseguir), terá canalizado a experimentação sexual e a excitação sexual, da mesma maneira gradual, das carícias nos seios, primeiramente, em direção à 


\section{"'Nada de sexo sob o meu teto': sexualidade adolescente nos EUA e nos Países Baixos a partir dos anos 1880"}

masturbação (punhetas) e, mais tarde, ao sexo oral (boquetes). No curso desta transição, "ir até o fim" irá se tornar o principal e, depois, o único critério entre os jovens quanto ao fato de se eles vivenciaram ou não o código adulto. Viver por ambos os códigos, jovem e adulto, era, de fato, viver sob um duplo padrão em relação ao sexo. A ponte entre os dois ficou conhecida como "virgindade técnica" e "fidelidade técnica".

Quando o encontro (dating) se tornou uma instituição social firmemente enraizada, um código específico para situações de negócios desenvolveu-se. Por volta dos anos 1980, nos EUA bem como na Europa, homens começaram a ser atacados por conta do assédio sexual. Em todo lugar isso implicou que, no trabalho, seduzir uma pessoa em uma posição social inferior tornou-se tabu, mas nos EUA, na prática, todos os flertes no trabalho foram marcados como assédio. Isso criou um distanciamento entre as condutas ligadas aos negócios - do qual sexo e sexualidade foram banidos - e as condutas relativas aos encontros, que se concentraram no sexo e na sexualidade. Desta forma, o domínio masculino foi institucionalizado sob uma dupla moralidade tripartida, a primeira, entre homens e mulheres, a segunda entre jovens e adultos (universitários), e uma terceira entre homens e mulheres no trabalho ou, quando se encontravam no "segundo turno" do trabalho, em casa (HOCHSCHILD, 1989, 1997). Em suma, o avanço de maior liberdade e independência das mulheres na América parece ter sido preservado acima de tudo no trabalho, apesar de a altos custos, e ter erodido fora do horário de trabalho.

Estas dificuldades na luta por maior igualdade para mulheres pode ser entendida, ao menos parcialmente, como um legado social do regime de encontros, no qual a dominação masculina naturalizada nos anos 1910 a 1920 foi formalizada, 
integrada e internalizada nos códigos e ideais, e mais ou menos fossilizada em anos subsequentes. Este enrijecimento pode ajudar a explicar por que, na segunda cultura jovem, quando a emancipação em relação aos regimes parentais foi logo seguida por um movimento pela emancipação feminina, o último teve repercussão mais chocante nos EUA que em países europeus. A persistência desta tradição demonstra o quão firmemente ela está socialmente enraizada, mas também o quão fortemente sua balança de poder desigual subjacente entre os sexos foi internalizada. Isto fez com que a tradicional dupla moralidade fosse e permanecesse mais forte que na Europa e isso ajuda a explicar por que, sobretudo, o avanço de maior liberdade e independência das mulheres na América diminuiu (WOUTERS, 2004).

Até o século XXI, as gerações de pais demandaram supervisão e, simultaneamente, mostraram pouca confiança na capacidade de os jovens supervisionarem a si mesmos (WOUTERS, 2004). Nos anos 1990, Amy Schalet descobriu em seu estudo de entrevistas, que os pais americanos acreditavam que suas proles tinham despertado hormônios de fúria e, por isso, incapazes de relacionamentos amorosos responsáveis (1994, 2011). Ao exigirem vigilância, os pais proporcionaram aos jovens um álibi para escapar da vigilância. De fato, eles criaram um clima "no qual garotos são mais propensos a terem suas primeiras relações sexuais em situações onde eles são capazes, ao menos, de estarem no controle, comportando-se racionalmente, ou terem uma experiência emocionalmente íntima: em festas e bêbados" (SCHALET 2003: 255). Assim, eles "aproveitaram-se" da imagem da sexualidade jovem como um campo minado de "hormônios raivosos" e "testosterona borbulhante". 


\section{"'Nada de sexo sob o meu teto': sexualidade adolescente nos EUA e nos Países Baixos a partir dos anos 1880"}

Ademais, os pais permitem a seus adolescentes algum "espaço" para escapar e "sair de fininho", enquanto eles "fingem não saber", praticando a política do "não pergunte, não fale". Aqui estão alguns exemplos desta política em relação às filhas: "oficialmente, Lisa, que atualmente está com quinze anos, não tem permissão para ter encontros até que tenha dezesseis. Mas Lisa tem um namorado e ela sabe que seus pais sabem mas eles "de fato não dizem uma palavra. Eles simplesmente deixam passar, eu acho'" (SCHALET, 2011, p. 124). E Caroline disse: "Eles não querem saber se eu estou fazendo isso" (SCHALET, 2011, p. 113). A política parece ser "parte de uma estratégia geral para esconder a maturação sexual das garotas adolescentes. A boa garota que todas as garotas procuram ser, e a maioria dos pais procura criar, não tem, parece, um eu sexual" (SCHALET, 2003, p. 196). Isto não está desvinculado, é claro, de os EUA ter a maior percentagem de gravidez na adolescência no Ocidente. Ainda, "sobre balança", Peter Stearns concluiu, "americanos decidiram identificar sexo, em vez de gravidez, como o principal problema quando menores são afetados" (1999, p. 243).

A política do "não pergunte, não fale" parece característica de uma balança de poder e de controles externos bastante desigual que proporciona aos pais, assim como aos filhos, "espaço" suficiente (e hipocrisia) para vivenciarem as regras estabelecidas, isto é, apenas na aparência... até eles alcançarem a idade dos dezoito anos ou irem para a faculdade.

\section{Enquanto isso, na Europa...}

Em países europeus como Inglaterra, Alemanha ou Países Baixos, todas as características do sistema de encontros 


\section{Cas Wouters}

não estavam presentes: não havia cidadelas de jovens, nem pontuar e encontrar, nem pagar e acariciar, dificilmente alguma pressão de pares e nada de competição aberta de popularidade ou "marcação de pontos". E durante a primeira metade do século $\mathrm{XX}$, as possibilidades de pessoas jovens e não casadas sentirem, tocarem e beijarem dificilmente vieram à tona para discussão, certamente não tão abertamente quanto nos EUA. Ademais, nas mesmas décadas em que "encontrar" (dating) espalhou-se e se estabeleceu nos EUA, a tendência europeia em direção à crescente liberdade nos regimes de acompanhamento e de cortejo implicou crescente aceitação social de um período para se conhecer um ao outro antes de um noivado. Este foi um período de "amizades" e "ficar estável", embora a última palavra não fosse usada nos livros de boas maneiras.

Ela não era usada nos livros de boas maneiras alemães porque ao discutir "assuntos do coração", os autores geralmente se restringiam à regra básica geral de ser aberto e honesto. Cortejar era percebido como pertencente ao mundo privado atrás das cenas públicas onde a máxima de Goethe Erlaubt ist was gefällt (o que agrada é permitido) predomina.

$\mathrm{Na}$ Europa britânica, famílias ricas e aristocráticas mantiveram o regime de acompanhamento com um rigor maior do que o fizeram as classes médias: "havia alguma insinuação de que a 'nova mulher', com sua bicicleta e atletismo, era um produto das classes médias". As classes altas ficaram para trás porque elas eram mais fortemente motivadas "a assegurar que a mulher conhecesse apenas candidatos apropriados" (CURTIN, 1987, p. 243). A este respeito, elas se comportavam como as classes altas americanas.

Os autores ingleses de livros de boas maneiras discutiam o nascimento das amizades, mas eles não discutiam o 


\section{"'Nada de sexo sob o meu teto': sexualidade adolescente nos EUA e nos Países Baixos a partir dos anos 1880"}

surgimento do "namoro" como um período anterior ao noivado. Eles permaneceram bastante vagos e nunca especificaram se beijar, tocar e afagos estavam dentro ou eram mantidos fora de uma amizade. Estas oportunidades e perigos sociais e sexuais permaneceram velados sob a advertência geral para "ser muito cuidadosa(o)". De fato, isso é "tipicamente Inglês". Para entender porque não havia outra expressão nestes livros, a não ser uma pálida "amizade", uma comparação com os Países Baixos parece útil, pois os autores de livros de boas maneiras holandeses eram um pouco mais diretos nestes assuntos.

\section{Os Países Baixos da Europa}

Nos Países Baixos, o começo do século XX viu uma erosão das acompanhantes, coincidindo com o surgimento das possibilidades de os jovens se conhecerem fora do alcance do controle de seus pais. Um autor notou: “a jovem garota costumava estar abatida pelo espartilho das convenções. [Hoje, contudo,] ela não está mais na sombra de sua mãe". Em contraste com os livros de boas maneiras ingleses e similares aos americanos, esta emancipação está relacionada à educação mista: "quando a filha terminava a escola, onde ela sentava frequentemente perto de garotos, na mesma sala de aula, ela estava um ser independente" (ECvdM, 1912, p. 266-68). Outro autor também escreve que a educação mista gera "uma atmosfera prazerosa e agradável entre jovens garotas e garotos em nosso país, em sua maior parte livre da censura da afetação e do maneirismo" (VIROFLAY, 1916, p. 83-4). Na Inglaterra, não muitas escolas tinham educação mista e a grande maioria das que tinham, estava educando crianças menores de doze 


\section{Cas Wouters}

anos de idade. Acima desta idade, garotos de pais que poderiam banca-la frequentariam uma "escola pública".

Os livros de boas maneiras holandeses proporcionavam alguma informação sobre ficar noiva(o). No início do século, uma autora ainda notou que o modo tradicional de anunciar um noivado consistia em o casal sair para uma caminhada juntos, mas ela adicionou: "hoje em dia, esta medida é antiquada, pois as jovens garotas de hoje não são mais mantidas apartadas dos jovens garotos tão meticulosamente quanto antes" (RAPPARD, 1912, p. 73). Simultaneamente, ficar noiva(o) estava perdendo algo de sua segurança enquanto uma solenidade ou comprometimento sagrado para casar dentro do tempo devido. Isto era expresso já no final do século XIX como, por exemplo, nas advertências contra as divertidas e despreocupadas "beaux" e "coquettes", com um histórico de noivados interrompidos (A, 1894, p. 27) e contra noivados curtos demais, por que eles poderiam dar margem a "suspeitar dos motivos do jovem rapaz" (ENGELBERTS, 1890, p. 78). As razões sugeridas foram que agarrar, beijar e tocar eram atividades que apenas um noivado permitiria oficialmente.

\subsection{Sexualidade e um noivado: entre tornar-se íntimo e a promessa de casamento}

Quando noivos, era esperado que um casal limitasse suas explorações sexuais. No entanto, os autores eram ambivalentes; seus conselhos deixavam claro que não se podia ir muito longe, mas também que era exatamente isso o que acontecia: "a completa expressão do amor, no entanto, deve ser guardada para o futuro marido. Se a troca de beijos durante um 


\section{"'Nada de sexo sob o meu teto': sexualidade adolescente nos EUA e nos Países Baixos a partir dos anos 1880"}

noivado se torna muito frequente, beijar no casamento terá perdido seu valor". Por isso a conclusão ambivalente: "levando tudo isso em consideração, faz sentido, se possível, não deixar o casal sozinho" (STAFFE, 1900, p. 98). Esta ambivalência é algo que faz lembrar a Sra Post, quem pelas mesmas razões decidiu contra qualquer jovem garota ir sozinha ao apartamento de um homem, e também do imperativo de Amy Vanderbilt dos anos 1950 ao início dos anos 1960: "para noivas de todas as idades, a sociedade espera o mesmo tipo de acompanhamento".

Outra recomendação holandesa do início do século XX dizia que, enquanto noiva, uma garota não poderia permitir quaisquer liberdades da qual ela teria se envergonhado antes, e continuou, dizendo que ela deveria mostrar a ele "que sua presença é a coisa mais preciosa do mundo para ela e que não há nada que ela preferiria mais que estar unida a ele para sempre, mas ela não deveria ir a lugares secretos e ermos". Pois "o jovem garoto poderá se sentir bastante alegre em um primeiro momento, mas logo ele desenvolverá uma aversão a isso e sua estima por ela cairá" (SEIDLER, [1911-15], p. 75). Isto é similar às garotas americanas tendo que fazer os melhores discernimentos entre complacência e rigidez. O motivo também é o mesmo: guardar-se para o casamento. Uma grande diferença, claro, é que encontros permitem desejo sem amor, enquanto um noivado, não.

No final do século XIX, autores começaram a dar voz a uma resignação pragmática sobre os "muitos noivados que são interrompidos mais de uma vez": um autor adverte contra anunciar um noivado de forma muito oficial ou pública como ao proclamar em um jornal. Pela mesma razão, recepções de noivado deveriam ser pequenas e íntimas, pois quanto maior o estilo da recepção, "mais as pessoas envolvidas se tornarão 


\section{Cas Wouters}

ridículas aos olhos do mundo, quando o vínculo for quebrado de novo" (WOUDE, 1898. p. 22, 25). Em 1911, Madame Etiquette ecoa bem antes um aviso sobre não fazer muito rebuliço em torno de um noivado, "pois, se ele acabar, o que acontece com certa frequência, então todas aquelas flores e festividades irão deixar todas as lembranças mais tristes ainda" (ECvdM, 1911, p. 188). No início dos anos 1920, é evidente uma maior atenção com as razões dadas para anunciar um noivado pelo envio de dois cartões separados: se o noivado estiver acabado, "não é agradável que um cartão de noivado seja mantido aqui e ali ou seja deixado perambulando por aí. Considerando o número de noivados que acabam, é aconselhado não enviar tantos cartões por aí" (MARGARETHA, 1921, p. 118-19).

\subsection{Falar sobre noivados, silenciar o verkering}

Nos anos 1920 e 1930, a tendência em direção a uma atitude mais maleável em relação aos noivados continuou (EGGERMONT, 1993, p. 111). Os pais foram ainda mais afastados da cena: agora os autores não apenas zombavam da "alarmante despreocupação" mostrada em noivar, mas eles também reclamavam de os jovens garotos e garotas não mostrarem respeito a seus pais, confrontando-os com o fato estabelecido de estarem noivos (MARGARETHA, 1921, p. 2930; BRUMMEL \& CO, 1927, p. 17). Neste contexto, a palavra verkering foi primeiramente usada para indicar o surgimento de uma relação de cortejo informal, sem compromisso fixo ou promessas cerimoniosas. A autora que a usou, reclama de um progredir do verkering para um noivado com o qual o casal abruptamente confronta os pais. Sobre tal união, ela escreve: 


\section{"'Nada de sexo sob o meu teto': sexualidade adolescente nos EUA e nos Países Baixos a partir dos anos 1880"}

É geralmente precedido por um período de flerte e escapadas [scharrelen] e metade da cidade ou todo o vilarejo sabe disso, exceto os pais. Quase sempre esse tipo de flerte e de escapadas [scharrelpartij] nem mesmo acontece em um relacionamento sério [vaste verkeeting]. E qualquer garota que já tenha experimentado mais de um desse tal scharrelpartij é caracteristicamente chamada, no popular, em um termo não muito cortês de: "rolo lambido" (ou "bicicleta da cidade"). (MARGARETHA, 1921, p. 143)

Estas palavras, scharrelen e verkering, estão cheias de dignidade e estas práticas não eram discutidas, embora esta citação sugira que a prática tornou-se estabelecida ao mesmo tempo em que os encontros. $\mathrm{O}$ termo verkering se popularizou mais ou menos ao mesmo tempo em que o dating nos EUA, isto é, dos anos 1880 em diante. Antes dos anos 1880, a conotação de cortejo do termo não existia; ele tinha o significado mais geral de estar em contato com ou em companhia de uma ou mais pessoas. Exemplos e referências no Woordenboek Nederlandse Taal (equivalente holandês do Oxford English Dictionary) sugerem que a palavra era usada de modo crescente para denotar uma relação de corte. Se um tal verkering durasse e a ligação entre os dois se tornasse mais séria e estável, o relacionamento se desenvolvia para vaste verkering, que pode ser traduzido como "namoro estável", porque a palavra vast significa "estável". Outra similaridade com os encontros é que a palavra e a prática foram desprezadas pelas classes altas e tornaram-se populares entre as classes médias, embora secretamente popular nos 
Países Baixos. Em contraste com o encontro, não se esperava que um casal que estivesse verkering tivesse relações similares paralelas. Esta diferença pode ser entendida a partir da vantagem de poder de uma juventude vivendo em cidadelas de jovens. As outras similaridades indicam que apesar das diferenças entre os EUA e a Europa, a emancipação da juventude e de sua sexualidade de debaixo dos regimes parentais testemunhou mais ou menos a mesma periodização.

$\mathrm{O}$ fato de apenas os noivados serem discutidos, não o verkering, implica em que os autores fiquem do lado do establishment e de seu código formal. Eles ignoraram o crescimento de um código informal, zombaram da "alarmante despreocupação" mostrada em relação ao noivado e estenderam seu desdém às quebras de noivados com similar desatenção. Uma autora declarou ser muito incorreto para uma jovem garota falar a seus pais, do nada, que estava noiva, e ela adiciona: "ainda assim, hoje, isso tudo acontece muito frequentemente. Há uma tendência, hoje, de simplesmente eliminar os pais destes importantes acontecimentos da vida e de deixar as decisões em suas próprias mãos. Que baixo e errado!" (KLOOS-REYNEKE VAN STUWE, 1927, p. 27). Outra autora observou um enfraquecimento do procedimento ritual de noivado:

Uma pessoa corteja em um carro, outra na praia, uma terceira sela o caso com um beijo, uma quarta pessoa beija primeiro, continua cortejando no dia seguinte e noiva dentro de uma semana. $\mathrm{O}$ consentimento dos pais tem se tornado um fator de terceira ordem. Em certos círculos proeminentes, nem se pede 


\section{"'Nada de sexo sob o meu teto': sexualidade adolescente nos EUA e nos Países Baixos a partir dos anos 1880"}

consentimento; os pais são informados do noivado apenas como um tipo de "notificação". A geração mais jovem tem progredido! (BRUMMELL \& CO., 1927, p. 17)

Nos anos 1930, autores continuaram a mirar os "noivados precipitados", que constrangem amigos e parentes a comprarem presentes e fazerem visitas, mas que são facilmente e silenciosamente invalidados: "Pim? Oh... você não sabia? Acabou há muito tempo!'” (ALSEN, 1936, p. 61; e HAEFTEN, 1936, p. 47). A popularidade de relações de cortejo sem serem "propriamente noivos" motivou esta autora a reclamar que, "em anos recentes, tem se sucedido um colapso da consciência moral", pois "muitos jovens não seriam capazes, em nenhum momento, de dizer com certeza se eles estão noivos ou não; muitos ainda deixam a seu critério se vai chamar ou não de noivado os relacionamentos deles com uma pessoa do sexo oposto" (ALSEN, 1936, p. 60). Estas palavras assinalam que tinha se tornado aceito para um casal apresentar-se como estando noivos sem terem passado pela formalidade - eles tinham verkering ou "vaste verkering", mas chamavam isso de verloving, um noivado. Ambos os autores de livros de boas maneiras e seu público evitaram o termo verkering.

\subsection{Ficando na cena: gedogen}

Na segunda metade dos anos 1930, o controle dos pais sobre a geração mais jovem tinha abrandado ao ponto de "pais sensatos" não pensarem em perguntar a um jovem rapaz quais as "intenções" dele quando ele passasse a dar um pouco de 


\section{Cas Wouters}

atenção extra às suas filhas, "nem mesmo se estivesse saindo com ela frequentemente". Eles poderiam falar sobre isso entre eles mesmos, mas "geralmente eles deixavam estas coisas inteiramente para os próprios jovens" (VEEN-WIKERS, 193640?, p. 93; também em 1946-50, p. 108). Mas os pais certamente esperavam que o casal confidenciasse a eles a tempo, não apenas tardiamente (POST, 1938: 116). Em face de tal ampliada margem de manobra, os pais eram aconselhados a aliviar as rédeas de seus filhos adolescentes pouco a pouco, pois se eles forem impedidos de aproveitar a liberdade agora permitida de forma muito rigorosa e insistente, "eles escaparão destas restrições de qualquer forma, e então correm o risco de começar, em alguma dança ou outra, casos totalmente condenáveis" (PAEUW, 1934, p. 205).

Estas palavras embasaram o motivo para praticar um tipo de tolerância que se espalhou nos Países Baixos e se tornou conhecida como gedogen: a permissão condicional de uma prática, geralmente combinada com uma política de dissuasão cautelosa. Gedogen permite àqueles que toleram a prática ficarem "na cena" e previne a prática de sumir no "submundo" e, assim, manter um olho controlador. A palavra gedogen remonta ao século XVI, quando seu significado era mais próximo a "aguentar" e "aturar", do que de "tolerar" e "permitir", mas os dois significados foram mantidos. Hoje, os melhores exemplos conhecidos de gedogen dizem respeito às drogas leves, à prostituição e à eutanásia, mas a palavra é usada, ainda, para práticas dos pais na criação dos filhos.

Depois da Segunda Guerra Mundial, nos anos 1950, foi observado que, devido aos "contatos muito livres" entre os jovens, a frequência de noivados teve uma queda. Cada vez mais este estágio foi ignorado, de acordo com esta autora, 


\section{"'Nada de sexo sob o meu teto': sexualidade adolescente nos EUA e nos Países Baixos a partir dos anos 1880"}

porque sem estarem formalmente noivos, os casais "têm toda a liberdade de que precisam para tomar uma decisão que diz respeito ao desejo de casar; eles podem fazer sexo na frequência e no nível de intimidade que desejarem" (SCHRIJVER, 1954, p. 43). Porém, através dos anos 1950 até o final dos anos 1960, muitas pessoas ainda se sentiam atraídas o suficiente pela tradição de noivar, para mantê-la viva.

\subsection{Sexualidade em noivados, namoro (dating) e verkering}

Em 1959, a liberdade sexual que vinha com um noivado nos Países Baixos era comparada à liberdade sexual oferecida pelo sistema de encontros nos EUA. A comparação foi feita em uma entrevista (Het Vaderland, 15 de agosto de 1959) com George Simpson, professor de Sociologia do Brooklyn College, em Nova York, na ocasião de seu retorno aos EUA depois de um ano ensinando na Leiden University. Simpson defendeu o sistema de encontros contra o então ataque comum (na Europa) de que, nele, garotos e garotas exploravam uns aos outros mutuamente. Dating não é um sistema tão rígido, foi registrado que ele disse, mas um meio positivo de iniciar a juventude americana na sexualidade saudável e de promover uma escolha madura do(a) parceiro(a). Neste ponto, de acordo com a opinião pública holandesa predominante, que ainda era fortemente contra o sexo pré-matrimonial, o jornalista holandês criticou Simpson, pois escreveu: "Prof. Simpson defende seu juízo de valor sobre o significado do 'dating' referindo-se à teoria freudiana de que a repressão dos desejos normais até o momento autorizado do casamento sempre será nocivo ao casamento. A iniciação e a preparação são para serem apreciadas como funcionais, isto é, como positivas". É no 


\section{Cas Wouters}

contexto desta defesa que foi dito que Simpson tinha apontado para a grande diferença, nos Países Baixos, entre casais noivos e não noivos, e ele é citado como tendo dito: "casais noivos de repente se permitem uma liberdade muito maior. Então um noivado é, aqui, realmente concebido como uma ligação garantida para a vida?" Ele tinha um ponto de vista, é claro, mas isso ofendeu os holandeses conservadores que queriam defender a fachada de status. Ao longo das décadas, os noivados tornaram-se cada vez mais sexualizados, assim como os encontros nos EUA, mas a sexualidade nos noivados era acobertada e separada do ideal de amor eterno. E é bastante revelador que nessa entrevista o verkering não foi mencionado em momento algum.

Mesmo Joke Smit, uma garota de classe média um tanto insubordinada, comumente reconhecida como tendo desencadeado a segunda onda feminista nos Países Baixos, alinhou-se àqueles que tentaram viver de acordo com o ideal estabelecido do sexo restrito a um noivado, ao menos aparentemente. No início dos anos 1950, ela e seu amigo Constant Kool tiveram um verkering, mas no dia em que ele chegou em Paris, no endereço onde ela estava como uma au pair $^{18}$ e onde eles dividiriam a mesma cama, eles se declararam noivos. Eles tinham dividido uma cama com certa frequência antes, mas discretamente, em particular (VUIJSJE, 2008, p. 109). Por fazer isso abertamente, eles quiseram o consentimento abençoado derivado de uma declaração de estarem noivos.

\subsection{Gedogen: rekken en erbij blijven}

${ }_{18}$ Uma pessoa, geralmente estrangeira, que faz trabalho doméstico ou cuida de crianças em troca de morada e comida. (N.R.T.) 


\section{"'Nada de sexo sob o meu teto': sexualidade adolescente nos EUA e nos Países Baixos a partir dos anos 1880"}

De 1939 até anos 1960, cada uma das doze edições de um famoso livro de boas maneiras holandês continha um conselho sobre tornar-se noivo e sobre acabar o noivado, mas não tinha nada sobre verkering ou sobre cortejar e sair, no sentido de dating; no entanto, na décima edição, publicada em 1953, isso foi adicionado:

O jovem que conhece seu mundo, visitará o pai da garota pela qual ele se sente atraído depois de encontrar-se com ela algumas vezes, e pede a permissão dele para sair com sua filha de vez em quando, então eles podem se conhecer melhor. ... A maioria dos pais apreciará esta atitude: ela previne encontros sorrateiros e mentiras. (GROSKAMP-TEN HAVE, 1953, p.25)

Estas palavras assinalam o surgimento de uma nova tradição de pais tentando "esperar" (erbij blijuen) e ficar na cena de seus filhos.

Por volta de 1960, esta nova tradição parece ter se estabelecido. Por um lado, ela é descrita como "muito normal também em círculos onde boas maneiras são tidas em alta estima, que uma garota é chamada para sair por diversos jovens sem ninguém dizer de forma desaprovadora que 'tem muitos garotos', pois 'uma garota é autorizada a ter tanto amigos homens, quanto mulheres" (PALTS-DE RIDDER E EIKHOF CA, 1960, p. 3). Por outro lado, os pais eram advertidos a estender sua hospitalidade a todos os amigos convenientes de seus filhos, homem e mulher, não de forma clara, mas casual e sutilmente. Desta forma, as autoras sugerem, os pais são capazes de manter um olho sobre seus filhos e suas orelhas perto da porta, permitindo, deste modo, ao menos algum 


\section{Cas Wouters}

controle sobre os contatos de seus filhos. E esta política do gedogen a bem de erbij blijven (segurar), foi novamente recomendada como a melhor forma de prevenir cortejos secretos em uma idade muito jovem (PALTS-DE RIDDER E EIKHOF CA, 1960, p. 4).

Em 1967, ambos, gedogen e erbij blijven, foram amalgamados pelo comediante nacionalmente amado Wim Sonnneveld como "rekken en erbij blijuen" (forçar o gedogen e [deste modo] ficar em cena). Isso aconteceu em um sketch - "tão holandês quanto o clima", em suas próprias palavras - no qual um pai, no dia do casamento de sua filha, discursa para a plateia sobre como ele a criou como uma igual, como uma amiga, completando que ele mesmo nunca perguntou ou contou a seus pais nada, mas fez como se os tivesse, e que a filha dele, como uma criança moderna, diz tudo a você, mas nunca faz o que você diz a ela. Então, quando ela levou para casa o primeiro namorado dela, ele não disse a ela que não gostava dele, mas elogiou o garoto, "o elogiou direto para a sepultura 19 ", o que se tornou uma expressão holandesa [comparável, até certo ponto, à inglesa: "ele o condenou com elogios idiotas $\left.{ }^{20 \prime}\right]$. Mas outros namorados vieram e eles foram todos bem-vindos à casa e à mesa de jantar, e esta prática do "rekken en erbij blijven" o tinha servido até este dia.

Rekken significa, literalmente, esticar ou prolongar o erbij blijven, e gedogen claramente é uma condição necessária para a prática do rekken. Rekken en erbij blijven tornou-se uma expressão holandesa bem conhecida e sua prática era e ainda é largamente advogada como a melhor política parental em relação aos seus filhos namoradouros. Obviamente, a prática também funcionou

19 ...he "praised him straight to the grave", no original. (Nota do Tradutor)

20 "he damned him with faint praise", no original. (Nota do Tradutor) 


\section{"'Nada de sexo sob o meu teto': sexualidade adolescente nos EUA e nos Países Baixos a partir dos anos 1880"}

para integrar o código (adulto) formal e o código (jovem) informal.

\subsection{A revolução expressiva e a sexual}

Foi apenas na Revolução Sexual que o código social proibindo sexo pré-marital foi abertamente atacado e, então, erodiu rapidamente. 1968 viu o primeiro survey nacional de sexologia (KOOIJ, 1968): uma maioria da população holandesa aceitou praticar controle de natalidade, apesar de eles aparentemente terem pouco conhecimento sobre isso. Aliás, contraceptivos só podiam ser comprados ilegalmente ou como um membro de uma associação. Metade da população era favorável à proibir rigorosamente contraceptivos para pessoas não casadas. Isto sugere que 1968 estava no final de um período de transição. Três anos mais tarde, o banimento legal de 1911, sobre a venda de contraceptivos, foi retirado.

O survey nacional seguinte, de 1974 (KOOIJ, 1976), mostra que entre 1968 e 1974, a Revolução Sexual tinha varrido os Países Baixos mais vigorosamente que em qualquer outro lugar. Não-casados vivendo juntos tinha se tornado aceitável e a percentagem de adolescentes reportando ter tido uma experiência sexual completa cresceu de 22, em 1968, para $40^{21}$. Quase três em cada quatro respondentes disseram que permitiriam sexo pré-marital se os dois "estivessem apaixonados" (era 1 em cada 4, em 1968), e três de cada cinco respondentes permitiriam sexo completo se um casal de jovens "tivesse fortes sentimentos um pelo outro" (era 1 em cada 5, em 1968). Os pais começaram, cada vez mais, a aceitar o sexo pré-

${ }^{21} \mathrm{Em}$ 2005, 30\% dos jovens entre 12 e 19 anos reportaram sexo completo. (Nota do autor) 
marital de seus filhos adolescentes, contanto que eles tivessem "fortes sentimentos um pelo outro" e estivessem "preparados para isso", isto é, preparados para o sexo como uma exploração de sentimentos físicos e pessoais. Baseados nisso, muitos pais permitiriam acariciar (42\%), mesmo dentro de casa (30\%). Mais de um em cada cinco pais (22\%) consentiria que seus filhos adolescentes "fossem até o fim", contanto que eles se restringissem a um parceiro, enquanto um pouco menos do que um em cada cinco pais (18\%) permitiria que isso acontecesse em casa (BOER, 1979).

Isto significa que entre os anos 1968 e 1974 uma tendência relativa à sexualidade adolescente apareceu e continuaria até os dias atuais: "ter fortes sentimentos um pelo outro" se tornaria a condição principal para fazer sexo e também para uma pernoitada romântica e sexual ${ }^{22}$. No mesmo período, o significado de "ter fortes sentimentos um pelo outro" mudou significativamente, porque muitos adolescentes agora reportavam ter amigos de outro gênero. Aprender a ter um relacionamento sexual implicava em aprender a ter um relacionamento. Neste processo, a tradicional máxima de que garotas amam garotos mais do que amam sexo, e garotos amam sexo mais do que amam garotas, começou a erodir. Ambos, garotos e garotas, gostavam de "ficar muito perto" e "deixar seu parceiro excitado" (BOER, 1978, p. 144), indicando que seus desejos de intimidade eram físicos e relacionais. Em 1989, esta

22 De fato, já no século XIX, "ter sentimentos fortes um pelo outro" era um critério maior para os pais consentirem em relação à atividade sexual de sua prole. Dois "parceiros adequados" precisavam expressar convincentemente estes fortes sentimentos um pelo outro, não apenas para seus pais, mas também para as famílias de seus pais. (Nota do autor) 


\section{"'Nada de sexo sob o meu teto': sexualidade adolescente nos EUA e nos Países Baixos a partir dos anos 1880"}

tendência continuou em direção à igualdade: a mesma quantidade de garotas e de garotos colegiais mencionou intimidade relacional e prazeres físicos (ambos acima de 70\%) como um motivo para fazer sexo (VOGELS \& VLIET, 1990, p. 71).

Em seu livro sobre sexualidade de adolescentes, Anita Ravesloot (1997) apresentou um vívido retrato das mudanças durante uma geração. No curso de diversos anos, ela perguntou à geração da "juventude dos anos 1980", nascida entre 1968 e 1972, sobre as experiências sexuais deles e ela também perguntou aos pais deles, da "juventude dos anos 1950", nascida entre 1938 e 1945, sobre quando eles mesmos eram adolescentes. A diferença entre as duas gerações parecia, sob um primeiro olhar, bem grande. Os pais foram totalmente criados sob a hierarquia tradicional de um chefe de família e sua esposa, do lar, submissa e mãe. Noivar, casar, ter e criar filhos e envelhecer juntos pertencia a uma ordem natural das coisas. As histórias da geração dos anos 1950 sobre sua juventude claramente exprime o quanto essas relações eram sentidas como opressivas. Em contrapartida, enquanto pais, eles permitiram a suas proles uma grande liberdade, também nas questões sexuais. Ideais de igualdade tinham crescido bastante, assim como a confiança dos pais na capacidade de autocontrole dos jovens, enquanto "rekken en erbij blijven" tinha se tornado uma prática familiar. Para os adolescentes, isto implicou na possibilidade de crescer em direção a fazer sexo quando um casal tem "fortes sentimentos um pelo outro" e mutuamente concordam estar "prontos para isso".

6.7. O legado social do verloving e do verkering 


\section{Cas Wouters}

Em 1995, ter "fortes sentimentos um pelo outro" bastava para três quartos como uma pré-condição para fazer sexo (BRUGMAN ET AL.), e este número passou a 80\% em 2005 (GRAAF ET AL). Em um estudo comparando famílias de classe média holandesas e americanas no início dos anos 1990, Amy Schalet concluiu que 9 em cada 10 pais holandeses mencionam estas condições para permitir a seus filhos adolescentes fazerem sexo "sob seus tetos", enquanto que 9 em cada 10 pais americanos nunca permitiriam isso $(2004,2011)$. Em 2010, uma replicação do questionário da pesquisa de Amy Schalet ratificou estes resultados (BRUGMAN E AL., 2010). Em 2003, um survey com grande escala de representatividade mostrou que $67 \%$ dos adolescentes holandeses entre 12 e 18 anos tinham permissão para dormir com a namorada ou namorado em seus quartos, na casa dos pais.

Este é o atual legado social da emancipação da sexualidade da juventude nos Países Baixos. Neste despertar, o ritual de noivar perdeu a maior parte de suas funções, e praticamente morreu. Atualmente, a palavra "verkering" ainda tem cheiro burguês e é, portanto, de uso limitado, mas, em muitos ouvidos, "verloven" (noivar) soa pomposo e fora de moda. Alguns falam ironicamente de sua noiva (ou noivo) ou de seu "amigo(a) fixo" ${ }^{23}$ e há muitas tentativas de encontrar expressões que captem ao menos alguns dos vários estágios dos desenvolvimentos de suas balanças de desejos e de suas relações sexuais, enquanto evitam as severas e rígidas conotações de classe, solenidade e hipocrisia. Em um veio

${ }^{23}$ Tradução direta de "steady friend", no original. Adaptado ao português brasileiro, o significado mais próximo seria o de uma pessoa com a qual se tem um relacionamento firme, estável, sério e de exclusividade em relação à parceria. (Nota do tradutor) 


\section{"'Nada de sexo sob o meu teto': sexualidade adolescente nos EUA e nos Países Baixos a partir dos anos 1880"}

similar, o termo "amor de estimação" 24 foi esquecido por ser muito depreciativo; isso pode ser tomado como um outro sinal de que "ter fortes sentimentos um pelo outro", amar e fazer amor são, cada vez mais, percebidos como um processo de aprendizagem do qual todos os estágios são levados a sério. Neste momento de transição, toda fase do desenvolvimento em direção a uma balança de desejos mais gratificante tem ganhado importância, tachando o termo "amor adolescente" como fora de moda, mas antes de um casal decidir casar, nenhuma dessas fases é sentida como sendo formal, isto é, ostensivamente importante, dando-se, assim, um pé na bunda no velho ritual de noivar.

\section{Uma visão teórica sobre livros de boas maneiras e as funções da "boa sociedade"}

A fim de responder a questão sobre porque esta virada do formal e conservador para o informal e liberal ocorreu de forma tão rápida e penetrante nos Países Baixos e de forma mais deficiente ou atrasada nos EUA, é preciso atenção à conexão entre livros de boas maneiras como fontes e as funções da "boa sociedade". Minhas principais fontes neste artigo, assim como em meus estudos "Sex and Manners" e "Informalization", são livros de boas maneiras. Eles são um gênero que existiu ao longo de todo o período pesquisado (e

${ }^{24}$ Tradução aproximada para "puppy love", no original, que seria, em uma tradução direta, "amor de cachorrinho". Segundo a reimpressão da 11 $1^{a}$ edição do Concise Oxford English Dictionary (2006), a expressão em questão significa, especificamente: amor intenso, mas relativamente vivido de maneira breve, tipicamente associado aos adolescentes. (Nota do tradutor) 


\section{Cas Wouters}

muito antes). Por isso, estes livros podem ser sistematicamente estudados por um período extenso. Os autores destes livros tentam capturar as sensibilidades, práticas e ideais que refletem os códigos dominantes, e vender este conhecimento a inseguros alpinistas sociais. Isso só pode se tornar explorado lucrativamente (publicado e vendido) se eles falarem convincentemente ao público que se identifica com o estabelecido na boa sociedade e aspira aceitação em seu grupo.

No começo do século $X X$, não seria prudente generalizar os códigos da boa sociedade, como formulado nos livros de boas maneiras, para além de uma pequena percentagem da população total - mas esta pequena percentagem era dominante. As pessoas nos centros dominantes de poder nutrem e defendem esse código, o que significa, a menos que os aspirantes os adotem, que há pouca ou nenhuma chance de sucesso social e mobilidade social para cima. É por isso que autores e leitores de livros de boas maneiras irão se identificar com os estabelecidos e irão orientar-se pelo código da boa sociedade, expressando ao menos apoio a ele da boca pra fora ${ }^{25}$. Quando grupos novos inteiros buscam emancipação e tornamse integrados, ou, de outra forma, quando a balança de poder em uma sociedade muda em outras direções, o código assim como sua retórica ${ }^{26}$ mudam.

No curso do século XX, o público que lia livros de boas maneiras expandiu. Autores vieram a se direcionar, cada vez mais, para uma ampla classe média e para círculos "respeitáveis" da classe trabalhadora e, por isso, livros de boas maneiras assim como a boa sociedade passaram a representar números crescentes de pessoas provenientes de mais e mais

${ }^{25}$ No original, "paying at least lip service to it". (N.R.T.)

${ }^{26}$ No original, "paying at least lip service to it". (N.R.T.) 


\section{“'Nada de sexo sob o meu teto': sexualidade adolescente nos EUA e nos Países Baixos a partir dos anos 1880"}

camadas da sociedade. Assim, estes livros refletem o crescimento no nível de integração social. Apesar de em algum momento particular essas informações estarem restritas ao estrato de pessoas que estavam se identificando com as classes estabelecidas e sua boa sociedade, o estudo das mudanças nos livros de boas maneiras abre uma janela específica para o crescimento do nível de integração social (WOUTERS, 2007).

Dentro de cada sociedade, o código dominante de boas maneiras e de auto-regulação é derivado da sociabilidade dentro dos centros de poder e de suas boas sociedades, que são os círculos de convivência social entre as famílias que pertencem aos centros de poder, e que tomam parte em seus eventos sociáveis, tais como jantares e festas. Boas sociedades e seus códigos têm três funções: 1) uma função modeladora; 2) uma função representacional; e 3) uma função de regular a mobilidade social e a competição por status. Estas três funções são também vigentes nos níveis mais baixos da boa sociedade, mais abaixo da gradação social, seja no interior ou nas províncias (ELIAS 2012; WOUTERS, 2007).

1) Como os códigos da boa sociedade são decisivos para fazer amigos e vínculos, para conseguir uma esposa desejável e para ganhar influência e reconhecimento, eles servem como um modelo para todos os aspirantes sociais - eles têm uma função modeladora. Até o século XIX, as cortes tinham essa função. Em comparação com os círculos de corte, os círculos posteriores de boa sociedade eram mais amplos e a sociabilidade neles era mais privada, o que fez a função modeladora da boa sociedade menos visível. A definição dominante das maneiras adequadas de estabelecer e manter relações, entretanto, permaneceu construída nestes círculos (ou seus equivalentes funcionais entre os estratos sociais mais baixos). 


\section{Cas Wouters}

2) Em qualquer época, os modos prevalecentes na boa sociedade tendem a refletir a balança de poder e dependência entre grupos estabelecidos e grupos outsiders, na sociedade mais ampla. À medida que cada vez mais camadas de uma sociedade tornam-se emancipadas e mais socialmente integradas, os códigos sociais da boa sociedade vêm a representar estas mesmas camadas - eles têm uma função representacional. O código de uma boa sociedade tende a refrear as emotividades de todos os grupos representados nelas; isso reflete $e$ representa a balança de poder entre todos aqueles grupos e estratos que estão integrados na sociedade como um todo.

3) Portanto, os códigos da boa sociedade também funcionam para regular a mobilidade social e a competição por status. $\mathrm{O}$ regime de boas maneiras deles não apenas regula a sociabilidade, mas também funciona como um mais ou menos refinado sistema de inclusão e exclusão, um instrumento para rastrear recém-chegados buscando entrar nos altos círculos da boa sociedade, ajudando, desse modo, a identificar e excluir os indesejáveis, e assegurando que os recém-ingressos assimilem o regime de boas maneiras e auto regulação predominante. Em muitos países do "Ocidente" do século XIX, um regime de boas maneiras cada vez mais formalizado - consistindo em um complicado sistema de apresentações, convites, visitas, cartões de convite para sair, "nas casas" 27 , recepções, jantares e tudo o mais - tinha esta função de regular tanto a entrada na boa sociedade quanto a exclusão dela.

Em regra, boas sociedades são tanto mais constrangedoras e eficazes em exercer essas três funções quanto mais elas tenham cerrado suas fileiras no topo. Isso as possibilita operar como uma unidade fechada ao regular a

${ }^{27}$ No original, "at homes". 
“'Nada de sexo sob o meu teto': sexualidade adolescente nos EUA e nos Países Baixos a partir dos anos 1880"

competição por status e a mobilidade social pela criação e destruição de reputações. Quanto mais elas estão unidas, mais seus controles sociais se estenderão através de bem lubrificados canais de fofoca para suas várias fileiras e domínios.

Isto significa que uma "boa sociedade" funciona de diferentes formas, em diferentes sociedades e em diferentes estágios de seus desenvolvimentos. Uma grande diferença entre os EUA e os Países Baixos tem sido que, nos EUA, muitas boas sociedades rivais têm se mantido em funcionamento, permitindo às pessoas procurarem entrada em uma "boa sociedade" rival ou em um estado diferente. Nos Países Baixos, a boa sociedade foi e tem permanecido homogênea o bastante para tornar esse movimento quase impossível.

\section{Explicando diferentes trajetórias nacionais na regulação da sexualidade adolescente}

Como os códigos da boa sociedade também envolvem a regulação da sexualidade, incluindo a sexualidade adolescente, parece óbvio, a partir desta perspectiva, procurar uma explicação comparando a estrutura dos centros de poder nacionais e o funcionamento de suas boas sociedades. A questão é: como e em que medida esta comparação ajuda a explicar diferenças e características nacionais?

8.1 A regulação da competição social e da sexualidade adolescente nos Países Baixos

A pequenez compacta dos Países Baixos permitiu coteries em pequena escala, como eles eram chamados, 
consistindo de relações firmes e sobrepostas com canais de fofoca multifacetados espalhados pelo país inteiro. Eles funcionavam como uma boa sociedade coesa, fazendo e desfazendo reputações, regulando a mobilidade social e instando as pessoas a conformarem-se ao código deles (AERTS E VELDE, 1998, p. 278). Por consequência, as coteries de pequena escala firmes e sobrepostas da boa sociedade holandesa tiveram uma vigorosa função modeladora, uma clara função representacional e efetivamente serviu para regular a competição e a mobilidade sociais.

Os membros da boa sociedade desenvolveram um estilo solene de serem deftig junto com a liberal e sóbria rigidez da deftigheid. Intimamente relacionada estava uma preocupação com distinções de stand, a palavra que eles preferiam a classe ou posição; uma pessoa não podia ter ligações com pessoas de um stand mais baixo. Até a metade dos anos 1960, os holandeses continuavam a usar e ainda a discutir diferenças de estamento ${ }^{28}$ de forma mais aberta do que na Inglaterra e em outros países europeus, onde as discussões públicas destas diferenças foram tabuizadas antes (WOUTERS, 2007).

As relações e maneiras do século XIX demoraram mais para desaparecer nos Países Baixos do que na Inglaterra, Alemanha ou França. Isto aponta para a persistência do tipo de estado pluralista tipicamente holandês, com negociações no topo, preparadas por negociações nos níveis mais baixos de

${ }^{28}$ No original, "stand", mas sem destaque em itálico como nos outros trechos. Em português, a maior aceitação da tradição weberiana fez prevalecer o termo "estamento" quando se trata de representar posições sociais impermeáveis entre si, em detrimento de "estado", utilizado em português brasileiro para apresentar as distinções estamentais na sociedade francesa anterior à revolução de 1789. 


\section{"'Nada de sexo sob o meu teto': sexualidade adolescente nos EUA e nos Países Baixos a partir dos anos 1880"}

integração, e muitas comissões, comitês e deliberações informais para fazer trabalho preliminar. Entre as razões para isso continuar tanto tempo até o século $X X$, estava um movimento da classe trabalhadora que, desde seu início, foi de orientação fortemente burguesa.

Também importante é o fato de que os Países Baixos não participaram da Primeira Guerra Mundial. As classes dirigentes holandesas logo retomaram o controle do país em acordo com os códigos pré-guerra. A verzuiling (pilarização ${ }^{29}$ ) tipicamente holandesa, o apoio a classes e segmentos de acordo com diferenças religiosas, também pressionou em direção ao conservadorismo, pois a competição por lealdade ao próprio zuil (pilar, denominação) tornou-se equivalente a ser leal de forma submissa às autoridades estabelecidas.

Nesta calção geral para manter os códigos e ideais tradicionais, os holandeses resolveram manter as aparências cada vez mais, criando, assim, uma fachada de correção e um vazio cada vez maior entre o comportamento em público e na vida privada, particularmente no tocante à sexualidade. Aqui, um caso significativo em questão é como os holandeses resolveram elogiar retoricamente a tradição de noivar e manter silêncio em relação ao verkering.

Depois da Segunda Guerra Mundial, representantes do establishment pré-guerra, tanto conservadores quanto progressistas, almejavam novamente a restauração da velha

29 Significa, em tradução direta, a "divisão ou organização da sociedade em grupos paralelos, cada um com sua própria hierarquia, baseada em diferenças religiosas ou ideológicas, especialmente na Holanda e na Bélgica" (Dicionário Oxford online). Disponível em: $<$ https://en.oxforddictionaries.com/definition/pillarization> Acesso: mar. 2017. 


\section{Cas Wouters}

ordem. A hierarquia tradicional e a deftigheid voltaram, apesar de muitas de suas arestas mais afiadas terem sido removidas. Ao mesmo tempo, o vazio entre os modos formais e as práticas informais cresceu a altos níveis de hipocrisia, mais alto do que em outros países.

Todo esse mundo desapareceu, por assim dizer, atrás de uma cortina de fumaça a partir de uma bomba de fumaça lançada em 1966, na carreata e desfile real por conta do casamento da princesa Beatrix e o príncipe Claus, em Amsterdã. A metáfora da cortina de fumaça transmite o sucesso da variante holandesa de um movimento internacional de protesto de jovens e estudantes para atacar a cultura burguesa inflexível: todo o mundo da deftigheid foi tirado de cena. Ataques à hipocrisia de lançar uma fachada de retidão fez dessa prática tão intolerável que mesmo os estabelecidos se juntaram à repentina mudança coletiva: havia um prazer coletivo em afastar-se da hipocrisia. Exibições antigas de standsbesef eram, agora, desprezadas e chamar alguém de deftig era marcá-lo ou marcá-la como um inflexível e arrogante fóssil de um mundo que tinha cessado de existir.

A virada do pêndulo foi das maneiras que inspiram hierarquia às condutas que inspiram igualdade. Na segunda metade dos anos 1960 e através dos anos 1970, autoridade, etiqueta e regras em geral permaneceram suspeitas o bastante para fazerem livros de boas maneiras tornarem-se fiascos comerciais: eles não foram publicados por mais de quinze anos (WOUTERS, 2007).

Deixando de lado as diferenças existentes na formação dos habitus, a principal razão pela qual a luta de gerações e a Revolução Sexual ${ }^{30}$ tiveram efeitos mais profundos e

${ }^{30}$ Em maiúsculas, no original. (N.R.T.) 


\section{"'Nada de sexo sob o meu teto': sexualidade adolescente nos EUA e nos Países Baixos a partir dos anos 1880"}

duradouros nos Países Baixos foi este hiato de hipocrisia que cresceu entre um front stage de fingimento rígido, e as realidades dos bastidores. Se as diferenças existentes na formação do habitus são levadas em conta, outrossim, eles ajudam a explicar porque os holandeses tomaram a liderança em diversas circunstâncias morais e legais. As velhas autoridades e as novas, chegando ao poder, continuaram a levar as questões de protesto e de direitos individuais a sério o suficiente para formar comitês, para negociar e comprometerem-se (KENNEDY, 1955). Elas se juntaram à rápida e intensa guinada do "gerenciamento por comando" para o "gerenciamento por negociação" (SWAAN, 1990), e é a partir da impregnação desta guinada na relação entre pais e filhos que a rápida mudança do "nada de sexo sob meu teto", para condicionais "pernoitadas", pode ser explicada.

Esta mudança em direção a um comprometimento mais profundo com a negociação e transigência, mais do que em outros países, implicou em um declínio da desigualdade social. Uma condição necessária à ocorrência deste declínio foi um nível relativamente alto de integração social nos Países Baixos em combinação com uma boa sociedade unificada, funcionando como uma ferramenta de abrandamento da competição social e do conflito. Isto promoveu um nível relativamente alto de confiança mútua, permitindo uma relativamente prematura legalização do casamento homossexual, da prostituição, do aborto, da eutanásia, das drogas leves, e também pavimentou o caminho para uma também prematura autorização de eventuais "pernoitadas" por parte dos adolescentes. Todas estas regulações expressavam um nível relativamente alto de autocontrole mutuamente esperado, as questões em jogo não são nem o controle, nem o descontrole, mas ambos: era uma 


\section{Cas Wouters}

tentativa de descontrole controlado, tanto socialmente, quanto individualmente (WOUTERS, 2004; 2007).

\subsection{A regulação da competição social e da sexualidade adolescente nos EUA}

Uma das razões de porque a mudança do formal e conservador, para o informal e liberal foi bem mais lenta e mais restrita nos EUA do que nos Países Baixos é porque, nos EUA, a desigualdade de gênero tinha se enrijecido no sistema de encontros. Esta desigualdade entre homens e mulheres esteve ligada a relações relativamente desiguais entre pais e filhos. Em meus estudos Sex and Manners e Informalization, eu tentei expor o poder explicativo da competição relativamente aberta entre muitas boas sociedades da América, e como esta competitividade tem impregnado na prática todas as condutas e relações americanas (ver também MENNELL, 2007; WOUTERS, 1998; 2011), incluindo as relações de gênero. Isto foi replicado em um sistema de encontros (dating system) altamente competitivo.

Uma competição social mais aberta e feroz desencadeia uma insegurança de status maior, o que ajuda a explicar o desenvolvimento de formas mais pronunciadas e acentuadas de gerenciamento da opinião, tal como vangloriar-se, o uso de superlativos ou exageros, e demonstrações relativamente abertas de sentimentos de superioridade. Estas maneiras americanas características, incluídas as maneiras dos encontros, são sintomáticas da incerteza da posição, de linhas de divisão social porosas e mutáveis. Em sociedades e círculos onde a competição e a mobilidade sociais são mais claramente reguladas e as posições sociais menos inseguras, o uso de 


\section{"'Nada de sexo sob o meu teto': sexualidade adolescente nos EUA e nos Países Baixos a partir dos anos 1880"}

superlativos tende a diminuir. Características nacionais como, por exemplo, um gosto por subavaliação, auto-escárnio, e ridicularizar ou "parodiar" 31 uma autoridade parece ter se desenvolvido apenas em estreita relação com 0 desenvolvimento de um sentimento mais intenso de comunidade, com uma inibição relativamente forte da raiva, isto é, em sociedades relativamente coesas e bem integradas.

A grande variedade de centros de poder concorrentes e suas boas sociedades, também tem poder explicativo para o desenvolvimento da pressão de iguais como um processo parcial do surgimento do regime de encontros (dating regime) em universidades. Os campi das universidades funcionaram como terrenos férteis para o desenvolvimento da pressão dos pares e permitiu ao jovem formar uma frente mais unida na negociação com pais e seus representantes do que os jovens nos interiores, onde os pais eram mais unidos no reforço dos códigos estabelecidos. Nos EUA, como faltava aos pais uma boa sociedade unida, os jovens podiam usar a solidariedade dos pares como um pé-de-cabra pela mudança. A mudança em questão foi o estabelecimento do sistema de encontros (dating system) nas universidades. Em casa, o ditado "não sob meu teto" foi mantido.

No sistema de encontros (dating system), a competição mais aberta da América e sua mais fraca regulação da mobilidade social, foi refletida e simultaneamente expressa nas palavras "ranquear e encontrar". Estas palavras indicam uma regulação da sexualidade adolescente com atitudes mais instrumentais e comerciais direcionadas à sexualidade em relações competitivas. Estes tipos de atitudes e de relações estenderam-se ao "pague e acaricie", portanto, provavelmente

31 "Send up", no original. (N.T.) 
fornecendo uma base para uma expansão consumista do sexo e do crescimento do número de "fêmeas porcas chauvinistas".

A questão de porque a mudança do formal e conservador, para o liberal e informal foi tão rápida e incisiva nos Países Baixos e mais deficiente ou lenta nos EUA, pode ser respondida também a partir da diferença nos arranjos do Estado de bem-estar. A relativa carência, nos EUA, indica um baixo nível de integração social e também parece relacionada ao "Sonho Americano" e sua celebração da autodeterminação individual. Para começar, o projeto de realização desta autodeterminação, não é visto como compatível com ainda viver em casa com seus pais, e o mesmo acontece com ter uma relação sexual completa. Em casa, o projeto do pai e sua autoridade geralmente prevalecem. $\mathrm{O}$ individualismo do tipo Horatio Alger $^{32}$ tem entrado no habitus americano a ponto de a busca proposital dos ideais e ideias individuais ser vivida como um direito inviolável do indivíduo e, assim, os arranjos do Estado de bem-estar são mais facilmente percebidos como uma ameaça, e logo rotulados de "socialismo" ou "comunismo".

Nos Países Baixos, um nível mais alto de integração e solidariedade sociais foi expresso na distribuição da riqueza via

32 Horatio Alger foi um escritor norte-americano que ficou conhecido por seus livros sobre jovens que buscavam escapar da pobreza pelo trabalho árduo, caracterizando-os como de uma retidão moral pura. Suas obras tiveram um papel formativo nos Estados Unidos, especialmente entre 1870 e 1900. A penetração de sua obra no repertório de representações de orgulho nacional norte-americano valeu o reconhecimento do argumento de seus romances como o "mito Horatio Alger", significando que a atitude empreendedora puramente individual, envolta por uma moral puritana, resultaria em ascensão social honesta (N.R.T.). 


\section{"'Nada de sexo sob o meu teto': sexualidade adolescente nos EUA e nos Países Baixos a partir dos anos 1880"}

arranjos do Estado de bem-estar social. Desde 1945, em um logo período de paz e de crescimento da "segurança social e pessoal", os arranjos de um Estado de bem-estar comprometido, removeram muitas arestas afiadas da competição por status e criou uma "paz" no que tange aos aspectos materiais, e uma diminuição significante do medo de ficar pobre. Aumento da riqueza e o suprimento de "segurança social" por uma renda mínima garantida pelo Estado têm sido particularmente importante para as mulheres em relação aos homens - as mulheres tornaram-se menos dependentes de seus pais e maridos - e para os adolescentes em relação a seus pais. As alternativas do Estado forneceram uma rede de segurança que aumentou a força delas nas negociações com maridos e pais. Ademais, a remuneração estudantil e o forte apoio a direitos, garantiu aos adolescentes serem menos dependentes do suporte financeiro de seus pais (WOUTERS, 1972). Isto gerou uma maior segurança e confiança pessoais, e sobre esta base, uma "equanimidade do Estado de bem-estar social" floresceu (STOLK \& WOUTERS, 1987; WOUTERS, 1990), particularmente no período no qual pernoitadas sexuais vieram a ser aceitas e se alastraram. Em comparação com suas contrapartes americanas, os adolescentes holandeses tomaram uma posição de relativa igualdade em relação a seus pais. Essa mudanças na balança de poder, uma virada completa de um "gerenciamento por comando" para um "gerenciamento por negociação", explica parcialmente as mudanças na regulação da sexualidade adolescente holandesa. Uma importante adição a esta explicação é a mudança nos estilos de criação coincidindo com a mudança na balança de poder: relações entre pais e filhos viram um declínio no nível de suspeita e medo, e um aumento 
no nível de expectativa de autocontroles mútuos, isto é, um crescimento da confiança mútua.

\section{Observações finais}

Nos Países Baixos, até os anos 1960, autores de livros de boas maneiras não mencionavam o verkering, embora esta fase de familiarização tenha se tornado uma prática bastante generalizada entre os anos 1880 e 1920. Verkering era considerado como não refinado ou vulgar e não era aceito pelas classes altas. A identificação com os estabelecidos, que serviu para manter uma boa sociedade homogênea funcionando durante muitas décadas, explica em grande parte porque pessoas jovens de famílias que pertenciam à boa sociedade ou dirigiam-se a partir de seus códigos, continuaram a celebrar a tradição da boa sociedade de noivar e mantiveram a disseminação do verkering nas sombras.

Autores holandeses não discutiam o verkering, provavelmente pela mesma razão pela qual a Senhora Post tinha evitado discutir as carícias: até mencioná-los poderia promover dignidade às práticas informais, "impróprias" e "vulgares" que "não têm lugar na sociedade distinta". Este motivo é corroborado pelo fato de que tanto as pessoas das classes altas americanas quanto das holandesas desprezavam essas práticas, e ambas, verkering e dating, tinham se espalhado predominantemente a partir das classes médias. Isto significa que a grande maioria de autores holandeses evitou mencionar o verkering pelo mesmo motivo que uma minoria de autores americanos evitou mencionar as carícias: identificação com os estabelecidos. A diferença é que a pressão do grupo de pares da classe média por trás do sistema de encontros (dating system) 


\section{"'Nada de sexo sob o meu teto': sexualidade adolescente nos EUA e nos Países Baixos a partir dos anos 1880"}

teve sucesso em integrar o sistema à cultura nacional estabelecida, considerando que verkering, nos Países Baixos, apesar de ser um costume popular, guardava uma posição de segunda classe, inferior ao verloven (noivar). A maioria dos autores americanos seguiu o sucesso do sistema de encontros (dating system) e a maioria dos autores holandeses seguiu o sucesso dos seus estabelecidos, assim como a população holandesa. Mas a profundidade de sua identificação com os estabelecidos tinha enfraquecido ao ponto onde vivenciar o ideal de noivar formalmente, para poder casar, foi cada vez mais se tornando uma fachada. Assim, enquanto praticavam o verkering, os holandeses fundaram uma tradição de retórica que apoiava a tradição dos estabelecidos, sem, de fato, o fazer.

Ao contrário de suas homólogas holandesas, as classes altas americanas não tiveram sucesso em manter a dominância de sua tradição cultural. Sob a pressão dos grupos de iguais e das classes médias, eles foram forçados a enfraquecer suas ambições. A identificação com os estabelecidos mudou desta forma: o estabelecimento do sistema de encontros foi experimentado como a libertação de uma tradição opressora. Nos Países Baixos, apenas a segunda metade dos anos 1960 trouxe uma experiência similar.

Além do diferente ritmo de emancipação da sexualidade, outra grande diferença envolve a balança de desejos. A palavra verkering se refere a uma relação, tanto enquanto uma regra, quanto como um ideal de intimidade relacional - fortes sentimentos um pelo outro - tem permanecido no coração e na origem da intimidade física. No dating, o sexo era menos embebido de amor, ele era menos relacional, e para os garotos, era permitido "ganhar algum" beijo, abraço e toque, mas apenas em relações passageiras que 


\section{Cas Wouters}

se tornavam cada vez mais instrumentais e comerciais, e apenas como uma fase transitória da juventude para a vida adulta, do universitário e seu fulgor (sexo e prazer), para o homem maduro e sua amada (amor e responsabilidade).

Esta formulação orientada para o macho está, agora, fora de moda, é claro, mas resultou da atitude de que garotosserão-garotos, a qual havia mantido sua validade, apesar de enfraquecida. Garotos tornando-se homens tem de mudar sua balança de desejos, de uma dominada pelo sexo para outra dominado pelo amor, o que, por si só, já é difícil o bastante não apenas para os garotos, mas também para as garotas, pense na "fêmea porca chauvinista" -, mas devido à celebração da autodeterminação individual, muitos garotos que estão se tornando homens sonham com uma esposa leal, mesmo submissa a seu projeto, para criar seus filhos. Comumente, o projeto dele de uma autodeterminação individual tem prioridade sobre o dela, e a menos que seu projeto consista em ser um pai, muitas mulheres podem ser iguais no trabalho, mas não como esposa ou como uma mãe. Nos Países Baixos, uma vez que o ideal tradicional da balança de desejos para os dois, homem e mulher, consistia em intimidade física ininterrupta, embebida em intimidade relacional, as mulheres têm tido melhores chances de se tornarem cada vez mais iguais no trabalho, assim como esposas e como mães. Os adolescentes têm se beneficiado, porque a crescente igualdade de gênero também abriu portas e deu motivos para uma crescente igualdade entre eles e seus pais.

A questão de porque os americanos mantiveram a tradição da abstinência sexual pré-marital e porque os holandeses inventaram e estabeleceram uma nova tradição de permitir o sexo pré-marital, mesmo dentro de casa, tem sido 
"'Nada de sexo sob o meu teto': sexualidade adolescente nos EUA e nos Países Baixos a partir dos anos 1880"

intrigante e inspiradora. É claro, há mais aspectos relevantes para o entendimento, interpretação e explanação destas diferenças do que aqueles que eu mencionei até aqui. Porém, eu espero que a descrição e a comparação apresentadas das duas trajetórias nacionais, tenha ao menos insinuado uma direção de uma resposta.

\section{Referências bibliográficas}

A. Doodgewone Dingen. In: De stijl van de burger. Aerts, Remieg e Henk te Velde (eds). Kampen: Kok. 1998.

ALSEN, Ola. Zoo zijn onze manieren. Een handleiding voor goede omgangsvormen. Leiden: Leidsche Uitgeversmaatschappij. (translated from the German). 1936.

BAILEY, Beth L. From Front Porch to Back Seat: Courtship in TwentiethCentury America. Baltimore and London: John Hopkins University Press. 1988.

BOER, J. de. Gevoelige kwesties omtrent seksuele kontakten van jongeren. Zeist: Nisso. 1978.

BOER, J. de. Behoedzame Ontmoediging. Zeist: Nisso. 1979.

BRUGMAN, Emily; GOEDHART, Hans; VOGELS, Ton; ZESSEN, Gertjan van. Jeugd en seks. Resultaten van het nationale scholierenonderzoek. Utrecht: SWP. 1995.

BRUGMAN, Margaret; CARON, Sandra L.; RADEMAKERS, Jany. Emerging Adolescent Sexuality: A Comparison of American and Dutch College Women's Experiences. In: International Journal of Sexual Health. Mar/2010. pp. 32-46. BRUMMELL \& CO. De Man op $z^{\prime} n$ best. Een geestige Handleiding in SavoirVivre. Den Haag: Moorman. 1927. 
CENTRAAL Bureau voor de Statistiek. Jeugd 2003, cijfers en feiten. Voorburg/Heerlen. 2003.

CRESSEY, Paul G. The Taxi-Dance Hall. A Sociological Study in Commercialized Recreation and City Life. New York: Ams Press. 1971. (Reimpressão de 1932, Chicago)

CALDWELL, Mark. A Short History of Rudeness. Manners, Morals, and Misbehaviors in Modern America. New York: Picador. 1999.

CURTIN, Michael. Propriety and Position. A Study of Victorian Manners. New York: Garland. 1987.

DAVIDOFF, Leonore. The Best Circles. Society, Etiquette and the Season. London: Croom Helm. 1973.

ECVDM. Het wetboek van Mevrouw Etiquette voor Heeren in zestien artikelen. Utrecht: Honig. 1911.

ECVDM. Het wetboek van mevrouw Etiquette in $\mathbf{3 2}$ artikelen. Utrecht: Honig (7ª ed.). 1912.

EGGERMONT, Patricia. Van houwen, trouwen (en berouwen). Informalisering rondom verloving, huwelijk en echtscheiding in Nederland, aan de hand van etiquettevoorschriften, 18501990. Tese de doutorado em História Social (doctoraalscriptie maatschappijgeschiedenis) defendida na Erasmus Universiteit Rotterdam. 1993.

ELDRIDGE, Elisabeth. Co-Ediquette. Poise and Popularity for Every Girl. New York: Dutton. 1936.

ELIAS, Norbert. On the Process of Civilisation: Sociogenetic and Psychogenetic Investigations. Dublin: UCD Press. 2012. [Collected Works. Vol. 3, 1939].

ENGELBERTS, D.H. De goede toon. Een wegwijzer etc. Amsterdam/De Rijp: Van Raven. 1890.

FASS, Paula S. The Damned and the Beautiful. American Youth in the 1920s. New York: Oxford University Press. 1977. 
"'Nada de sexo sob o meu teto': sexualidade adolescente nos EUA e nos Países Baixos a partir dos anos 1880"

GORER, Geoffrey. The American People. A study in national character. New York: Norton \& Co. 1948. [Impresso em 1959 as: The Americans: A Study in National Character. London: Arrow].

GRAAF, Hanneke de; MEIJER, Suzanne; POELMAN, Jos; VANWESENBEECK, Ine. Seks onder je 25e. Seksuele gezondheid van jongeren in Nederland anno 2005. Delft: Eburon. 2005.

GROSKAMP-TEN HAVE, Amy. Hoe Hoort Het Eigenlijk? Amsterdam: Becht. 1939. [1-3 ed: 1939; 4-5 ed: 1940; 6: 1941; 7: 1942; 8: 1947; 9: 1948; 10: 1953; 11: 1954; 12: 1957; 13: 1966]

HAEFTEN, Olga van. Manieren. Wenken voor wie zich correct willen gedragen. Amsterdam: Kosmos. 1936. [2nd ed. 1937, identical]

HEMPHILL, C. Dallett. Bowing to Necessities. A History of Manners in America 1620-1860. Oxford UP. 1999.

HOCHSCHILD, Arlie Russell; MACHUNG, Anne. The Second Shift: Working Parents and the Revolution. New York: Viking Press. 1989.

HOCHSCHILD, Arlie Russell. The Time Bind: When work becomes home and home becomes work. New York: Holt, Metropolitan Books. 1997.

JONATHAN, Norton Hughes. Gentlemen Aren't Sissies, (A modern Guide Book for the Young Man About Town). Chicago: Winston. 1938.

KENNEDY, James C. Nieuw Babylon in Aanbouw: Nederland in de Jaren Zestig. Amsterdam: Boom. 1995.

KENNEDY, James C. 'New Babylon and the politics of modernity,' Sociologische Gids. XLIV: 361-74. 1997.

KLOOS-REYNEKE VAN STUWE, Jeanne. Gevoelsbeschaving. Rotterdam: Nijgh \& Van Ditmar. 1927. 
KNAP, Henri. Zo zijn onze manieren. Amsterdam: Bezige Bij. 1961.

KOOY, G.A. Sex in Nederland. Utrecht: Het Spectrum. 1968.

KOOY, G.A. Jongeren en seksualiteit. Sociologische analyse van een revolutionaire evolutie. Deventer: Van Loghum Slaterus. 1976.

LEVY, Ariel. Female Chauvinist Pigs: Woman and the Rise of Raunch Culture. New York: Free Press. 2005.

MARGARETHA, Anthonia. Vormen en manieren. De eischen der Wellevendheid toegelicht voor onze Christelijke Kringen. Kampen: Kok. 1921.

MCGINNIS, Tom. A Girl's Guide to Dating and Going Steady. Garden City, NY: Doubleday. 1968.

MEAD, Margaret. Part Four: The Two Sexes in Contemporary America. In: Male and Female: A study of the sexes in a changing world. London: Gollancz. 1950.

MENNELL, Stephen. The American Civilizing Process. Cambridge: Polity. 2007.

PAEUW, L. de. Nette manieren. Een handboek der wellevendheid voor jong en oud. Baarle-Hertog: De Belgische Boekhandel. 2 $2^{\mathrm{a}}$ ed. 1934.

PALTS-DE RIDDER, Yvonne; EIKHOF, Vera. Hoe het "hoort". Van kennismaking tot huwelijk. Regina Goede Raad Serie Nr. 3, Haarlem: de Spaarnestad. Aprox. 1960.

PIERCE, Beatrice. Etiquette for Young Moderns. Home Service Booklets. 1937.

PORTER, Cecil. Not Without A Chaperone: Modes and Manners from 1897 to 1914. London: New English Library. 1972. 
"'Nada de sexo sob o meu teto': sexualidade adolescente nos EUA e nos Países Baixos a partir dos anos 1880"

POST, Emily. Etiquette in Society, in Business, in Politics and at Home. New York: Funk and Wagnalls. 1922. (edições revisadas: 1923; 1927; 1931; 1934; 1937; 1942; 1950; 1960)

POST, Toos. Zoo Hoort Het. Wellevendheid als uiting van innerlijke beschaving en liefde tot den evenmensch. Utrecht: Urbi et Orbi. 3ํe ed. 1938.

RAPPARD, Jonkvr. H.A. Goede manieren. Wat men doen en laten moet in het dagelijksch leven. Haarlem: Visser, $3^{\underline{a}}$ edição melhorada e expandida. 1912. (1롤 $1909 ; 2^{\mathrm{a}}: 1910 ; 4^{\mathrm{a}}$ : 1920)

RAVESLOOT, Janita. Seksualiteit in de jeugdfase vroeger en nu. Ouders en jongeren aan het woord. Amsterdam: Het Spinhuis. 1997.

SCHALET, Amy Townsend. Dramatiseren of normaliseren? De culturele constructie van tienerseksualiteit in de Verenigde Staten en Nederland. In: Amsterdams Sociologisch Tijdschrift. no 21 (2). Pp. 113-47. 1994.

SCHALET, Amy Townsend. Raging Hormones, Regulated Love: Adolescent Sexuality and the Constitution of the Modern Individual in the United States and the Netherlands. Dissertação de mestrado. University of California, Berkeley. 2003.

SCHALET, Amy. Must we fear adolescent sexuality?: Not under my roof. In: Medscape General Medicine. 29/12/2004. Disponível em: <http://www.medscape.com/viewarticle/494933_8> SCHALET, Amy. Not Under My Roof: Parents, Teens, and the Culture of Sex. Chicago and London: Chicago University Press. 2011.

SCHLESINGER, Arthur M. Learning How to Behave: A Historical Study of American Etiquette Books. New York: Macmillan. 1946. 
SCHNABEL, Paul. Jeugd en seks. In: NRC Handelsblad. 14-031998.

SCHRIJVER, Elka. Kleine gids voor goede manieren. Assen: Born. 1954. (reimpressões: 1959; 1962)

SEIDLER, Dr. H.J. Hoe men zich bij de heeren het best bemind kan maken. Rotterdam: Bolle. Aprox. 1911-15.

SONNEVELD, Wim. Conferência De Jongens (texto: Simon Carmiggelt). 1967.

STAFFE, Baronesse. Bestemming. Dochter, Echtgenoote, Moeder. Livremente editado para o francês por G.J Bakker Korff-Hoogeboom. Amsterdam: C.L.G. Veldt. 1900s.

STEARNS, Peter N.; KNAPP, Mark. Men and Romantic Love: Pinpointing a Twentieth-Century Change. In: Journal of Social History. N. 26 (4). Pp. 769-95. 1992.

STEARNS, Peter N. Battle Ground of Desire. The struggle for self-control in modern America. New York University Press. 1999.

STOLK, Bram van; WOUTERS, Cas. Frauen im Zwiespalt. Frankfurt/M: Suhrkamp. 1987.

SWAAN, Abram de. The Management of Normality. Critical Essays in Health and Welfare. London: Routledge. 1990.

VANDERBILT, Amy. Amy Vanderbilt's Complete Book of Etiquette, A Guide to Gracious Living. New York: Doubleday. 1952. (reimpressões: 1958; 1963; 1972)

VEEN-WIJERS, Olga van. Etiquette. Encyclopedie der correcte omgangsvormen. 's-Gravenhage: Succes. Universiteit voor zelfstudie. 1936/40. (1936-1940, e ainda 1946-50)

VIROFLAY, Marguérite de. Plichten en Vormen voor Beschaafde Menschen. Amsterdam: Cohen Zonen. 1916 e 1919. VOGELS, A.; VLIET, R. van der. Jeugd en seks. Gedrag en gezondheidsrisico's bij scholieren. SDU, Den Haag. 1990. 
“NNada de sexo sob o meu teto': sexualidade adolescente nos EUA e nos Países Baixos a partir dos anos 1880"

VUIJSJE, Marja. Joke Smit. Biografie van een feministe. Amsterdam: Atlas. 2008.

WADE, Margaret. Social Usage in America. New York: Crowell. 1924.

WALLER, Willard. The Rating and Dating Complex. In: American Sociological Review. N. 2. Pp. 727-34. 1937.

WOUDE, Johanna van. Vormen. Handboek voor dames. Amsterdam: Van Holkema en Warendorf. 1898.

WOUTERS, Cas. On Youth and Student Protest. In: Transactions of the Seventh World Congress of Sociology. Varna, September 14-9-1970. Vol. III. Sofia: International Sociological Association: 197-205. 1972.

WOUTERS, Cas. Van minnen en sterven. Informalisering van de omgangsvormen rond seks en dood. Amsterdam: Bakker. 1990.

WOUTERS, Cas. Etiquette Books and Emotion Management in the Twentieth Century: American Habitus in International Comparison. In: STEARNS, Peter N.; LEWIS, Jan (eds.). An Emotional History of the United States. New York: NY UP, 283-04. 1998.

WOUTERS, Cas. Sex and Manners. Female Emancipation in the West 1890 - 2000. London: Sage. 2004.

WOUTERS, Cas. Informalization: Manners and Emotions since 1890. London: Sage. 2007.

WOUTERS, Cas. Status Competition and the Development of an American Habitus. In: BUSCHENDORF, Christa; FRANKE, Astrid; VOELZ, Johannes (eds.). Civilizing and Decivilizing Processes: Figurational Approaches to American Culture. Cambridge Scholars Publishing. Pp. 263-286. 2011. 